\title{
MACROECONOMIC IMPLICATIONS OF THE NEW ECONOMY
}

\author{
Martin Neil Baily \\ Senior Fellow, \\ Institute for International Economics
}

Author's note: Trond Augdal has provided excellent research assistance. Helpful comments were received by Morris Goldstein, John Haltiwanger, Catherine Mann, Adam Posen, Daniel Sichel, Jack Triplett, Ted Truman and by Takatoshi Ito and John Taylor, the paper's discussants.

The views expressed are the author's own and do not represent those of the Institute, its staff, or trustees. 


\section{INTRODUCTION}

Together with many policymakers and economists, I see in the 1990s expansion signs that new technologies that had been emerging for some time were finally paying off in stronger economic performance. I will use the expression 'new economy' to describe this period, although I recognize the pitfalls in this name. New economy is probably too broad a term and implies both more change and more permanent change than actually took place. But 'information economy' seems too narrow a term to describe the set of interrelated forces bringing about change in the economy, that include increased globalization, a more intense pressure of competition, the rapid development, adoption and use of information and communications technology (IT) and a favorable economic policy environment.

The paper is a survey, drawing on a range of literature and covering a variety of topics. The goal is to give the reader a sense of some of the macroeconomic issues that have developed as a result of the surprising economic performance of the 1990s expansion, including some sense of what is known and not known about accelerated productivity growth, the key driver of the new economy.

With the license of a survey paper I have not tried to tell a linear story or link each section of the paper together, but there are, nonetheless, two main themes. The first is to explore the relation between IT, on the one hand, and economic performance on the other. One view of the new economy is that it reflects an exogenous surge in innovation and capability in the hightech sector. That view is not simply wrong, but it is seriously misleading. It is misleading because the innovations that are required to make productive use of IT are as important as the high-tech innovations themselves. ${ }^{1}$ It is misleading because innovation is strongly demand driven, so that the old or traditional economy was a vital driver of innovation in high-tech. It is misleading because the overall economic and policy environment is essential if high-tech innovation is to translate into superior economic growth. In particular, a highly competitive economic environment in which new companies enter and expand and old companies contract or die is one that fosters the adoption of innovation.

The second theme of the paper is to emphasize the uncertainty that currently surrounds the new economy and how much hangs on whether or not it continues. IT has been around for a long time and will continue to contribute to the economy for some time to come. But the period over which innovation has translated into accelerated productivity growth is very short-a mere

\footnotetext{
${ }^{1}$ On this issue see for example Brynjolfsson and Hitt (2000).
} 
five years. The Economic Report of the President in January 2001 described the uncertainty involved:

"The fact of a shift in the trend of structural productivity growth does not tell us how permanent that shift will turn out to be.....We could be observing not a long-term shift to a faster productivity growth rate but simply a shift to a higher level of productivity, with faster growth for a while followed by a return to the pre-1995 trend." (28)

Faster productivity growth has translated into lower unemployment and inflation and greatly improved real wages. It has been a key factor behind the strength of the stock market, the rapid inflow of foreign capital and the strong dollar. If the productivity growth trend falters going forward, the adjustment that the US economy would have to go through would be painful. This paper was delivered at the conference prior to the terrorist attack of September11, 2001. At this time it is not clear how this will affect the US and the global economy. At the very least, it increases the uncertainty of the economic outlook.

\section{MACROECONOMIC PERFORMANCE IN THE 1990s: A RETURN TO THE NEW ECONOMY?}

The performance of the US economy after World War II was very strong with rapid GDP growth, relatively low unemployment and moderate inflation. Compared to the problems of war and the turmoil of the depression, a new, stronger, and more stable economy emerged. After 1973, economic performance deteriorated and chronic problems with inflation, unemployment, and slower growth arose. The first two rows of table 1 illustrate the contrast. Real GDP growth dropped by nearly a third after 1973 and GDP per capita growth dropped slightly more than that. Average unemployment rose by nearly 40 percent and average inflation more than doubled.

How does the decade of the 1990s compare? The period 1990 to 2000 as a whole looks pretty good compared to the 1973-90 period in terms of inflation and unemployment. Both variables improved greatly, and compare well with the golden years before 1973. In terms of growth, the story is not so clear. Growth for the whole decade was ahead of the slow growth period after 1973, but slower than in the 1960s. In fact, all of the growth acceleration is concentrated in the second half of the decade. The five years after 1995 are a remarkable but very short period of rapid growth, low unemployment, and low inflation.

One of the most remarkable signs of a new economy has been the strong performance of the US stock market. However, evaluating the performance of the market is very sensitive to starting and ending points. I have not included returns data in table 1 because the table's time 
periods do not fit the movements of the market very well. Based on the real total return to holding the S\&P portfolio of stocks, the market performed strongly after World War II, yielding 9.9 percent a year from 1947-72. ${ }^{2}$ The growth over this period was not smooth, however, with a 13.9 percent return 1947-59 and 6.1 percent from 1959-72.

After 1972 the market was very weak, yielding essentially a zero return (-0.18 percent a year) from the first quarter of 1973 until the first quarter of 1983. Returns were strong after that, with a return of 10.6 percent a year through the end of 1994, pretty much a return to the post 1947 period. Starting in 1995, the market went through another inflection point, yielding a 25.6 annual rate of return through the first quarter of 2000. Recent market weakness has meant that for the four quarters through the first quarter of 2001, the return has been -15.6 percent.

Despite the weakness over the past year, the rise in the market value of corporate equities has been astounding. In the 1980s, the market value of US corporations (debt and equity) was well below the replacement cost of the physical capital owned by those corporations (Tobin's Q was less than unity). By 1990 this had changed and Tobin's Q was around unity and by 2000 Tobin's Q was close to 2. ${ }^{3}$ Earnings price ratios and dividend price ratios for S\&P stocks by the late 90 s were at their lowest levels of the entire period since 1959.

The final column of table 1 shows the average value of the current account deficit over the periods shown, as percentages of GDP. The period of rapid growth after 1995 stands out as a period of large external deficits. By 2000, the deficit was around 4.5 percent of GDP. The strong stock market and the capital inflow are linked phenomena. Strong returns to corporate capital in the United States and high, expected future returns both increased the value of the US stock market and attracted foreign investors, which pushed up the value of the dollar and attracted more foreign investors. The availability of foreign capital has been an important source of funds to the US economy.

The US current and capital accounts are, of course, codetermined, but it seems fair to argue that the attraction of high returns in the United States has pushed up the dollar and generated a large trade deficit, putting intense pressure on US manufacturing industries.

In summary, there are intriguing signs from the 1990s that we have returned to the kind of strong economic performance that prevailed after World War II. But to be cautious, most of these signs have only been around for about five years.

\footnotetext{
${ }^{2}$ These returns are calculated on the assumption that all dividends are reinvested. The implicit price deflator for non-farm business output adjusts for inflation.

${ }^{3}$ Robert Hall (2000).
} 


\section{ACCOUNTING FOR THE PRODUCTIVITY ACCELERATION}

The rapid rate of US economic growth achieved after World War II was largely driven by productivity growth close to 3 percent a year, while the slowing of growth after 1973 was associated with a sharp slowdown in productivity to 1.4 percent a year. Similarly, the strong growth of the US economy after 1995 is linked to a recovery of productivity growth. ${ }^{4}$ Table 2 gives four alternative estimates of the extent and sources of this productivity acceleration and all four estimates show a large increase in labor productivity growth in the nonfarm business sector (line 1). It appears there was a substantial revival of labor productivity growth in the second half of the 1990s.

In breaking down the sources of the productivity acceleration, the four estimates show similarities and differences. All four indicate that the rapid accumulation of high-tech capital over this period pushed up the rate of labor productivity growth (line 3). Three of the four suggest that a slowing in the rate of accumulation of other capital (line 4) partially offset the labor productivity contribution from the high-tech capital boom, however, so the acceleration in overall multifactor productivity (MFP) is estimated to contribute half or more of the total productivity acceleration (line 7).

The increased rate of MFP growth shown in table 2 is broken into two pieces. The production of computer hardware, and the semiconductors that go into the computers, contribute heavily to the MFP acceleration. All four estimates also show some increase in the rate of MFP growth in the broad economy - that is, the part of the economy not involved directly in computer production (line 9).

The Oliner-Sichel and Gordon estimates share several common elements--Gordon takes the Oliner-Sichel numbers as his starting point. One difference is that Gordon makes explicit the impact of the changes in productivity measurement methodology that took place over the period (the measurement effect is included in line 1 and then subtracted off in line 5). This difference is only a matter of presentation, not of substance, however. Gordon's other difference with OlinerSichel is to use a cyclical adjustment figure estimated by the Congressional Budget Office of 0.3 percent a year. This gives him a smaller residual MFP acceleration in the broad economy of 0.29 percent a year, compared with 0.59 in Oliner-Sichel. Oliner and Sichel do not exclude the possibility of a cyclical component to the productivity revival, it is just that they do not estimate what that component might be.

\footnotetext{
${ }^{4}$ The preliminary estimates suggested labor productivity growth had returned to around a 3 percent growth rate. The latest revisions have dropped this figure closer to 2.5 percent a year.
} 
Dale Jorgenson and Kevin Stiroh (2000, updated in 2001. See also Jorgenson 2001) use a somewhat different approach than the other authors in the table. They cover the whole business economy and include consumer durables as part of the capital stock (and the services from these durables as part of output). They also end their analysis in 1999, which makes some difference, given that 2000 was a strong year for productivity growth. Despite these differences, they end up with a residual MFP acceleration in the broad economy of 0.4 percent a year, not so different from the other estimates.

The estimates made by the Clinton Council of Economic Advisers of the acceleration of labor productivity is larger than the others because CEA measured output growth as an average of growth from the income as well as the output side of the National Income Accounts. Since income has been growing faster than production (the statistical discrepancy has increased), this adds to the estimated acceleration of productivity by 0.25 percent a year. The second difference involves the cyclical adjustment. CEA estimated trend and cycle using a model where firms make a partial adjustment of their labor input when their desired level of labor input changes. This analysis concluded that the effect of the cycle on the level of productivity was about the same in both 1995 and 2000, hence the growth of productivity between the two years was estimated to be about equal to its trend. (The same model does predict weak productivity in a slowing economy, as we are seeing now. $)^{5}$

Because of the larger estimate of the overall acceleration and the very small cyclical correction, CEA found that there was a large acceleration of MFP in the broad economy, equal to a full 1 percent a year. If correct, these results would indicate the broad economy has found new ways to improve its productivity over and above the effect of more IT capital.

How do these different results look in the light of recent events and new data? First, I judge that averaging the income and product sides of the National Accounts is a reasonable procedure. There is useful information on both the income and product sides of the accounts. The income data link directly to estimates of unit costs, relevant for inflation. It is possible that productivity from the output side is being understated because the survey data used to compile shipments and sales can become out of date in a rapidly changing economy. When the 1997 business census results were compiled, the product side estimates were boosted and this may happen again following the 2002 census. On the income side, there is the possibility that income has been over-estimated as capital gains income may have been incorrectly included in GDI.

\footnotetext{
${ }^{5}$ Steven Braun of the CEA staff carried out the productivity decomposition reported in table 2 under my direction.
} 
Averaging the two is ad hoc, but is better than simply ignoring valuable information from the income data.

What about the cyclical effects? The weakness in productivity in the past few quarters seems no more than would be expected given the sharp decline in output and employment. The CEA results on the impact of the cycle still seem reasonable. ${ }^{6}$ But as the 2001 Economic Report noted, it is very hard to separate out trend from cycle with only a few years of data and other economists have reached different conclusions than did CEA. ${ }^{7}$ Furthermore, there may well have been a temporary component to the strong productivity growth after 1995 resulting from unusual factors that were not picked up in a cyclical adjustment equation, but will not persist. ${ }^{8}$ For example, the surge in retail throughput allowed the wholesale and retail sectors to boost their productivity to an extraordinary extent. And the surge of financial activity induced a sharp rise in measured productivity in the financial sector. (See the next section for a discussion of the industry data).

What about data revisions? There has been an important change in the data since the estimates in table 2 were made. The Bureau of Economic Analysis has released revised estimates of GDP that reduce the estimated growth of nonfarm business output 1997-2000. The figures for investment in equipment and software in 1999 and 2000 were sharply reduced, largely coming from the software component. The hours of work data have also been revised. The impact of these revisions is to reduce the rate of labor productivity growth estimated from the product side of the National Income Accounts by 0.35 percentage point a year over the period 1995-2000. The downward revisions to the income side, to GDI, were smaller than those on the product side however, so the (already large) statistical discrepancy has widened further.

The revisions to the data, plus the likelihood that part of the post-1995 acceleration was temporary suggest that the CEA figure of 1 percentage point as the acceleration in structural MFP in the broad (noncomputer) sector of the economy was too high. As the current downturn plays out we will get a clearer picture of what has happened, but for this discussion I will take 0.5 percent a year as a working estimate, instead of 1 percent. Taking this figure, there are some clear lessons from the growth accounting exercise.

\footnotetext{
${ }^{6}$ Cyclical dynamics are explored in Baily, Bartelsman and Haltiwanger (2001). Basu, Fernald, and Shapiro (2001) and Roberts (2001) also conclude that little of the post-1995 productivity acceleration was cyclical. ${ }^{7}$ Gordon (2000) has estimated his own cyclical correction and, as noted earlier, has also used the estimates from the Congressional Budget Office. Oliner and Sichel's analysis is of actual not structural productivity, so they do not estimate a cyclical effect at all.

${ }^{8}$ One argument is that in the extraordinarily tight labor market, employees were working more hours than were being recorded. This is possible, however, Lucy Elridge, Marilyn Manser, Phyllis Otto, and Brooks Robinson (2001) compare CPS and BLS estimates of hours worked and find no sign of an unmeasured boost to hours after 1995 that would change estimates of the productivity acceleration.
} 
Conclusions from Accounting for the Acceleration. First, the current sharp slowdown in output and labor input growth will yield a period of below trend productivity growth. Despite differences in approach between Gordon and CEA in measuring the impact of the cycle, this prediction follows directly from either analysis. No great surprise there, since labor productivity growth slowed sharply starting in the third quarter of $2000 .{ }^{9}$ However, given the weakness in the economy, the fact that labor productivity has averaged 1.46 percent over the four quarters ending in the second quarter of 2001 can be seen as encouraging. If 1.46 percent is below trend, then the trend must be pretty good.

The next message is that IT mattered. The surge of productivity within the high-tech sector itself drove a large fraction of the productivity acceleration. The computer and semiconductor sectors (largely the latter) contributed 0.3 percent a year to the acceleration of productivity growth. The fact that the United States is a major producer of high-tech products and that the pace of technical change accelerated has been a reason why the US grew so rapidly in the late 1990s. Over and above its direct contribution to growth the high-tech sector was a major driver of the investment boom as it sharply lowered the price of investment goods.

However, it is the wrong message to describe the contribution from high-tech capital deepening as springing purely from some exogenous event in the high-tech sector. The tremendous demand for high-tech capital came about because companies were finding profitable and productive ways to use the capital. Large users of high-tech capital, such as financial services, business services, and retailing, were not buying the capital goods just because they were cheap. They were buying them because they saw technology as essential to their success in a competitive environment. Fiscal policy and the inflow of foreign capital kept down interest rates and the cost of capital and contributed to the high level of investment.

The rapid growth and dynamism of the US high-tech sector was and is endogenous. It is indeed changing traditional industries, but is also being driven by the demand from traditional industries.

The acceleration of MFP in the broad economy reinforces this same story. Not only have traditional or old economy industries been able to use IT hardware effectively, they have found additional ways to increase their productivity.

To develop these conclusions further, I turn now to the data on the acceleration of productivity by industry.

\footnotetext{
${ }^{9}$ Uncertainty about changes in the number of self employed hours worked likely overstated productivity in the fourth quarter of 2000 and understated it in the first quarter of 2001.
} 


\section{THE PRODUCTIVITY ACCELERATION IN THE INDUSTRY DATA}

Table 3 uses BEA data to show labor productivity growth by industry from 1989-95 and 1995-99. Each industry's output reflects the value added in that industry (gross product originating) and labor input is measured by number of full-time equivalent employees. The table reveals that non goods-producing industries account for much of the acceleration of labor productivity. Large service industries such as wholesale and retail trade, finance and business services have all had increases in labor productivity growth greater than for the economy as a whole. There has been much discussion of the importance of supply-chain management improvements enabled by IT (see Litan [2001] for example). And it is striking that wholesale and retail trade increased their productivity growth by well over 4 percentage points after 1995 .

The acceleration in trade seems almost too much, however. This is a sector that is not normally subject to cyclical fluctuations, but in the late 1990s American consumers went on a buying spree and increased throughput dramatically in this sector. This created an opportunity for rapid labor productivity growth that may not survive the downturn. This sector may have given a temporary boost to overall productivity in the late 1990s.

Finance is a sector that has invested heavily in IT. It achieved strong productivity growth pre-1995 and even stronger growth post-1995. Within finance, however, it turns out that "holding and other investment offices" and "security and commodity brokers" are the industries that have achieved the surge in productivity, not banks. The surge in financial market activity boosted fees and output from these financial services industries. Business services, another heavy IT user has shifted from negative growth pre-1995 to solid positive growth post-1995.

Durable manufacturing had stellar productivity growth before 1995 and even more stellar growth afterwards (this sector of the economy includes computer hardware production), but other goods-producing industries did less well. Overall, the post-1995 productivity acceleration in goods industries was less that that in the private industry total.

Some service industries might have been expected to show IT-related improvements that did not do so. For example the telecom industry actually shows slower growth after 1995, probably because this industry has been changing so much and investing heavily in developing its networks. Despite these exceptions to the general rule, the last two rows of table 3 show support for the view that IT has helped growth. The industries were ranked by IT intensity based on their IT spending relative to value added. They were then divided into two groups, the less and the more intense IT users. The intense IT using industries showed much faster labor productivity 
growth over the entire period 1989-99, and showed about a 50 percent larger acceleration after 1995.

Other economists have also analyzed the industry data and assessed the role of IT. William Nordhaus (2001) and Kevin Stiroh (2001) reached similar conclusions to those above. The increase in labor productivity growth is broad-based across industries and is linked to the use of IT. Robert Gordon (2001b) provides valuable additional insight into the industry data by comparing the BEA data with the BLS industry series. He points to inconsistencies in the data, encouraging caution in interpretation of any industry patterns. In the end, however, he also argues that the revival of productivity is broad-based. He stresses that this conclusion emerges from looking at gross output per hour not from the value added figures shown in table 3. Gordon is more skeptical about the link between IT and the labor productivity revival based on his review of the industry data.

Conclusions on the Acceleration and the Industry Data. There are pitfalls in any industrylevel analysis of productivity because the data are not collected in a way that really allows the researcher to allocate outputs and inputs by industry, particularly inputs. Deciding which industries are using IT capital intensely is problematic, for example. But if you put together the findings from the growth accounting exercise with the pattern of the industry labor productivity data in table 3 , the combination is pretty suggestive. It does not prove that innovations enabled by IT are contributing to labor productivity in a number of industries, including service industries, but it is certainly consistent with that view.

\section{WHY THE ACCELERATION IN THE 1990s? AND WILL IT LAST?}

There was a large literature in the 1980s attempting to understand why productivity growth slowed after 1973. It was not a very satisfying literature, in that no clear consensus emerged. Initially, it looked as if the rise in energy costs had to be the explanation, certainly the timing looked right. But that explanation stalled out because energy costs are not a big enough share of total cost. Moreover, the trend of slow productivity growth continued even after energy prices fell again.

There may be a lesson there, that trying to explain or predict the turning points in the productivity trend may not be possible. One simple way to describe the shifts in the productivity trend is that there was a pool of innovations and investments to be exploited after World War II, 
and these generated the fast trend of productivity over the period. There was then a lull as the low-hanging fruit had all been picked. During the 1970s and 1980s there was a lot of change taking place and old capital was being destroyed. ${ }^{10}$ There was an ongoing push of economic change and innovation, and the IT revolution was in the making, but the benefits did not show up, at least in measured productivity. Some time in the 1990s a new flow of productivity-enhancing innovations came on stream, the economic environment was favorable, and there has been a return to something closer to the postwar trend of faster growth.

While it is somewhat speculative, I think one can also see some of the reasons why the environment in the US economy in the 1990s was favorable both for rapid innovation and rapid diffusion of innovation. There has been heightened competition in an increasingly deregulated economy facing strong international competition. IT innovation is driven by the demand for improved technologies in the using industries. The United States has competitive service industries, often on a global scale, and this encourages them to seek out new technologies to improve their own productivity. Wholesale and retail trade, finance and telecommunications purchase almost seventy percent of all IT products. If the new economy were entirely the result of a random surge in the flow of innovation, then all countries should have had similar changes together. The new technologies are available globally. In practice the United States has been well ahead of most of the industrial countries and a reason for this is that the United States has competitive markets in the industries that are using IT.

Using the improvements in computing and communications technologies, companies are outsourcing parts of the value chain, extending the benefits of comparative advantage. This has resulted in substantial downsizing of large corporations. At the same time, IT often involves production with high fixed costs and low marginal costs, so that achieving a large market share in the area of core competence is often essential.

New forms of financing have contributed to the changes in organization. R\&D is risky and historically this made it difficult for small companies to get funding for technology development. The rapid growth of venture capital has alleviated this problem, facilitating an increase in small-firm R\&D.

When innovations occur in one area, it can bring benefits. But when complementary innovations occur together the effects can be greatly increased. The combination of rapid advances in computing power, software and communications capabilities form such a set of complementary innovations. Large amounts of data can be processed and presented in a way

\footnotetext{
${ }^{10}$ See Greenwood and Jovanovic (1999) and Baily (1981).
} 
nontechnical personnel can use and then transmitted to remote locations within the same firm or to other firms.

Supply chain management is a clear example of how complementary innovations have helped productivity and performance. A retail purchase is the last step in a long chain that includes raw material suppliers, component manufacturers, assemblers, wholesalers and retailers. These are linked in a chain that involves ordering, invoicing, sorting, loading and unloading, and shipping. Each step uses resources and creates potential mistakes, shortages or excess inventories. New management systems, facilitated by IT, have improved supply chain management by eliminating steps and reducing paperwork, fluctuations in production and inventory (see for example, Roy Shapiro [2000] and Richard Wise and David Morrison [2000]). ${ }^{11}$

The policy environment in the 1990s in the United States contributed to the creation of the right environment for growth and innovation. Policies to maintain domestic competition and increase international competition have been stressed. Funds have been provided to support basic research and education. And most importantly, the mix of monetary and fiscal policy has lowered interest rates and encouraged investment.

What does all this say about the future productivity trend? Gordon is pessimistic. He believes the productivity revival came from cyclical effects and from the surge in productivity growth within the computer sector. The huge rate of decline in computer prices of the past five years cannot continue indefinitely, he argues, and there will inevitably be diminishing returns to investment in IT capital. That reasoning is not so clear, however. First, there seems to be no immediate sign that IT prices have dramatically slowed their rate of descent as the technological drivers of improved performance are still at work. ${ }^{12}$ And even if the price declines do moderate, there is an offset, a "share effect."13 The share of IT capital in total capital has been rising rapidly, with the effect of pushing up the rate of real capital accumulation. The growth rate of the total capital stock is a weighted average of the growth rates of the components. The faster-growing components (IT equipment) are a growing share of the total.

What about the acceleration of MFP in the broad economy? An acceleration of 0.5 percent a year is a big improvement compared to close to zero MFP growth in this part of the economy since 1973. One could argue that this part of the acceleration is more structural and

\footnotetext{
${ }^{11}$ The improvements in inventory management have not stopped companies from

${ }^{12}$ For example, John Markoff reports in the June $30^{\text {th }}$ New York Times (2001) on an advance made at Intel "demonstrating that the semiconductor industry will be able to continue shrinking its basic building blocks at a torrid pace at least until the end of this decade."

${ }^{13}$ Daniel Sichel has pointed this out.
} 
likely to persist longer. Thus this argues for a return to good productivity growth once the economy recovers. But this reasoning is not that solid either. With no clear theory or evidence as to why this part of MFP accelerated, there is no strong basis for knowing how long it will last.

In the 2001 Economic Report we forecast labor productivity growth to be in the range of 2-2.5 percent a year going forward. That was on the low side compared with private forecasts at the time, but those private forecasts have been coming down lately. With the latest revisions to the productivity data, the lower end of the above range seems more likely than the upper end. This would be far better than the 1973-95 trend, but lower than the pace of the post World War II period.

\section{THE NEW ECONOMY IN OTHER INDUSTRIAL COUNTRIES}

Comparing US economic performance to other industrial countries adds insight to our understanding of the causes of the new economy in the United States. It can also suggest policy challenges for other industrial countries that are concerned they are missing out on new economy growth opportunities.

Data prepared by Bart van Ark of the University of Groningen, working with the Conference Board and drawing on OECD and World Bank sources, provide up-to-information on the pattern of GDP per capita convergence or divergence. A summary of the results is shown in table $4 .^{14}$

The table includes low- and middle-income developing countries as well as developed; since I thought it would be of some interest see how a broad group of different regions or countries have performed. But this paper cannot do justice to a discussion of development issues, and so I will concentrate on the United States, Europe, and Japan.

Convergence in the Developed Economies. The contrast in economic performance between the US and Japan is remarkable. From the 1950s until 1991, Japan was rapidly catching up to the United States; per capita GDP had risen to 89 percent of the US level. In the 1990s, as table 4 indicates, the relative level of GDP per capita in Japan declined. It had reached 74 percent by 2000 .

The European economies did better than the Japanese economy in the 1990s, but their convergence process stopped around 1980, earlier than did Japan's. According to table 4, the

\footnotetext{
${ }^{14}$ The growth for the United States is a bit different than that shown in table 1. Table 1 is based on BEA data.
} 
growth rate of GDP per capita in Europe and the United States were about the same from 1980 to 1995. Both the United States and Europe grew faster after 1995, but the gap widened significantly. With the United States indexed to equal 100, per capita GDP in the EU in 2000 was only 69, a gap with the United States of 31 percent. Of course the EU includes some countries that are not yet fully industrialized, but that does not explain much of the gap since France was at 72 , Germany was at 73 , Italy was at 70 , and the UK was at 69 --all pretty close to the EU mean. In short, the major European industrial countries, the EU as a whole and Japan are all operating at a level of economic activity that is three quarters of the US level, or a bit below. And over the period 1995 to 2000, the US had both faster employment growth and faster labor productivity growth than any of the large European economies or Japan. ${ }^{15}$

The fact that per capita GDP in the large industrial countries is clustered in the range of 69 to 74 percent of the United States conceals some sharp differences. GDP per capita can be broken down into two variables: how many hours a country's residents work and how much is produced by each hour (output per hour or productivity). A country can get to a given level of GDP per capita by having a low employment economy with high productivity or vice versa. Figure 1 plots these two variables with 2000 GDP per hour on the vertical axis and hours worked per capita on the horizontal axis. And we see that all of these countries except the United States are stretched along a downward sloping curve (the curve is simply an "isoquant" of constant GDP per capita). To reach roughly the same level of GDP per capita, France has high productivity and low employment, while Japan has low productivity and high employment.

There is one obvious reason why a group of countries would be stretched along a downward sloping curve. If an economy has low employment, this will concentrate economic activity on the most productive workers and jobs. But there is not a fixed tradeoff here. There are other factors at work and the position of the United States on figure 1 shows it. The United States is on a much higher isoquant than the EU and Japan on the figure. It has higher employment than any of the countries except Japan and also has the highest level of productivity. The United States is the only large country that has been able to combine full employment with high productivity.

A country's citizens make different tradeoffs between the amount of work they want to perform and the amount of income they want to receive. Europeans may choose more leisure and be willing to accept a lower GDP. Given that unemployment is high in Europe and that early retirement and reductions in work-hours have been imposed, individuals may not be making free

\footnotetext{
${ }^{15}$ I am excluding the small European countries, such as Finland or Ireland, although many are included in the EU total. The lessons from these countries (especially the case of Ireland whose per capita GDP now exceeds that of Germany or France) would support the argument to follow.
} 
choices about their labor-leisure tradeoff. But regardless, any country is better off if it makes its choices along a tradeoff curve that is as far to the northeast in figure 1 as possible. The challenge for France is to keep expanding employment, but to do so by creating high productivity jobs. The challenge for Japan is to raise productivity and maintain a desirable level of full employment. The challenge for the EU as a whole is to increase both productivity and employment. Policies that increase a country's economic efficiency and that encourage the productive use of new technologies will give its citizens the best options, even if it chooses to exercise those options very differently than does the United States.

\section{Box 1 Measurement Issues}

Differences in measurement methodology have been suggested as an explanation for the faster growth rate of GDP in the United States in the 1990s compared to other countries. In particular, the United States uses hedonic price indexes for computers and only some European countries do the same. It does not appear, however, that measurement issues are significant or even go in the direction of overstating US relative growth. Christopher Gust and Jaime Marquez (2000) at the Federal Reserve in Washington and Paul Schreyer of the OECD (2001) reviewed differences in measurement methodology and concluded that, while there are differences in approach, they did not significantly change the growth comparisons. I conducted an alternative check using the OECD's GDP comparisons made with purchasing power parity exchange rates. These comparisons apply a common measurement approach to all countries and determine each country's GDP relative to the United States, measured in a common set of prices in a given benchmark year. By comparing different benchmarks over time, one can see which countries have GDP growing faster than the United States (closing the gap) and which countries are growing slower (widening the gap) and by how much. These comparisons suggested that the domestic measurement methods in Germany and France slightly overstated their GDP growth 1990-96 relative to the US approach to measuring GDP growth. Italy, Japan, and the UK slightly understated their growth.

A final measurement issue arises because the international comparisons described above use total GDP rather than the output of the business sectors of the economies. In work carried out at the McKinsey Global Institute (1997), estimates were made of market sector GDP which suggested that productivity in France and Germany relative to the United States declined roughly 10 percentage points when government and nonprofit sectors were excluded. OECD data imply low relative productivity for health care, education and other nonmarket segments in the United States. Measuring productivity in the non-market sectors of an economy is very difficult. If we were to restrict our discussion only to market sector GDP, the productivity gap between the United States and the EU would widen. (See the discussion in Baily and Solow 2001).

To what extent does this pattern have any relation to the new or information economy?

One can make the case that it does not. First, Japan has a very strong high-tech sector. According to the OECD (2000) the share of IT production in GDP in Japan is larger than in the United States. And yet Japanese economic performance has been dreadful in the 1990s. Second, the European countries stopped converging to the United States in the 1980s, before the current excitement about the new information economy. Third, in terms of productivity growth over the decade of the 1990s as a whole (measured by GDP per hour), the United States and Europe grew 
at about the same rate and Japan grew slightly faster. US productivity did grow faster 1995 to 2000 , but more slowly in the prior 5 years.

These arguments provide an appropriate warning that the role of information technology in relative economic performance should not be exaggerated. IT alone is certainly not the only reason or even the main reason for the lack of convergence between the United States and the other countries. However, there are answers to these points. Since Europe and Japan start with per capita GDPs well below that of the United States, the expectation from the convergence literature results would be that these economies could grow faster than the United States. Since Europe and Japan were eliminating large amounts of employment, while the United States was adding millions of relatively low-skill employees to the workforce, productivity growth could have been expected to be much faster there than in the United States. The fact that they were not, suggests Europe and Japan were not exploiting the benefits of new technologies effectively.

Bart van Ark (2001) recently completed a detailed empirical analysis of the contribution of IT (ICT in his terminology) to growth in ten developed economies and his conclusions support this view: “....productivity growth differentials between the United States and most European countries are partly explained by a larger and more productive ICT-producing sector in the United States, but also by bigger productivity contributions from ICT-using industries and services in the United States. The main reason for the productivity deceleration in most European countries is due to the underperformance of the non-ICT sector." 16

- I will make the case that the interaction between IT and other factors is important. Specifically, barriers to the process of creative destruction, and particularly a lower level of competitive intensity in Europe and Japan, have prevented a more complete convergence. And since exploiting IT is encouraged by competition and requires change, the same barriers have also slowed the pace of adoption of new technologies.

The Importance of Competition Against Best Practice. ${ }^{17}$ One traditional way of judging whether or not a market is competitive is to compute an index reflecting market shares in relation to number of competitors. On that basis many industries that really are not very competitive may look quite competitive. In retailing, for example, there may be hundreds or even thousands of

\footnotetext{
${ }^{16}$ van Ark (2001) abstract.

${ }^{17}$ This section draws on the findings of a series of productivity and employment studies by the McKinsey Global Institute that compared the United States, European countries and Japan. A summary of results is in Baily and Solow (2001).
} 
competitors. In a manufacturing industry, perhaps there are dozens of suppliers of components. But in both of these cases, it is quite possible that the degree of competitive intensity that really matters is rather low. The retail competitors can be mostly small proprietorships or "mom and pop" stores. These stores are protected from competition from highly productive, "best-practice," multinational competitors by laws that prevent price cutting, or zoning rules that make it hard for the most productive retail formats to expand. These high productivity stores include the discounters like Wal-Mart or Carrefour, but also include higher-service specialty chains like Gap that rely on shopping malls to gather retail traffic.

Among manufacturers there may be explicit trade barriers that protect less productive companies and there may be more subtle forms of preference, tied to subsidies from regional governments or low-cost financing. Strong ties among companies and local preferences among consumers can also act as barriers to entry and competition against best practice.

Effective competition often involves industry consolidation and a reduction in the number of competitors. Weaker companies disappear, and this in turn often means job losses and dislocations that are painful for workers and communities. The costs of adjustment provoke hostility to the process of "globalization," in which best-practice companies apply their skills in a worldwide context. If this process is impeded, however, economic performance will suffer. The importance of structural change in industries to US productivity growth has been demonstrated by studies using the Longitudinal Research Database at the Census Bureau. A substantial fraction of the increase of productivity over time comes from the expansion of market share of productive establishments at the expense of less productive establishments. ${ }^{18}$

There is substantial resistance to globalization within the United States and trade barriers, including antidumping provisions, have protected inefficient producers in the United States. But the US economy has the advantage of being a large single market and has been that way for a long time. When "voluntary" trade restrictions limited auto imports from Japan, the Japanese companies came and set up high productivity plants in the United States, forcing the domestic industry to adjust. Shoppers in any given region in the United States do not care or even know where the store they buy from is headquartered, and zoning laws are flexible, so high productivity retail formats have spread nationwide. The introduction of trigger prices for imported steel in the late 1970s had a limited impact because mini mills sprang up to compete effectively against the established integrated producers.

\footnotetext{
${ }^{18}$ The work carried out at the Center for Economic Studies at the Bureau of the Census (led by Robert McGuckin, John Haltiwanger, Brad Jensen, and others) documented the process of change in manufacturing and services over this period. See for example, Baily, Hulten, and Campbell (1992) and Foster, Haltiwanger, and Krizan (2001).
} 
- The McKinsey studies concluded that domestic competitive intensity in the United States is very high, despite some policy lapses. By contrast, competitive intensity in Europe and Japan is much lower. When competitive intensity is high, companies are constantly forced to find ways to improve their operations or develop new products or services. This encourages the use of new technologies and encourages the search to find productive ways of using these new technologies. The best policy for encouraging the new economy is to encourage competition and create the demand for the new technology.

Prices as an Indicator of Competitive Intensity. The formation of the European Union and the creation of a single market are cited as evidence that Europe, at least, has created high competitive intensity in its traded goods sector. For many European countries, trade is a much larger share of GDP than for the United States. Perhaps the arguments given above are appropriate for services, but European manufacturing is surely competitive.

Ongoing research by Scott Bradford and Robert Lawrence suggests otherwise. ${ }^{19}$ Starting with commodity price data collected by the OECD for 1996, Bradford and Lawrence stripped out the impact of taxes and distribution margins to estimate producer prices for a detailed list of manufactured goods. They then found the lowest price for each good anywhere among the set of countries. This price was indexed to unity. The price for the same good relative to the lowest price was then calculated, indicating the extent to which the local price exceeded the "world" low price. A weighted average of the prices for each country was then calculated to determine the extent to which each country's manufactured goods prices, on average, exceeded the world low prices. $^{20}$

- Prices in the United States, on average, were 15 percent above the lowest prices. For Germany the figure was 62 percent. The UK was 42 percent, and the Netherlands was 60 percent. Japan's prices on average were 85 percent above the lowest prices. These price data support the view that openness and competitive intensity are substantially lower in Europe and Japan than in the United States.

\footnotetext{
19 The data were kindly supplied by the authors.

20 The Bradford and Lawrence data included agricultural goods, but these do not change the averages significantly.
} 
The Importance of Labor Market Flexibility. One view of the rise in European unemployment in the 1980s is that jobs were lost in traditional or old-economy industries, but new attractive jobs were not created on a sufficient scale. Supported by generous unemployment, disability or early retirement programs, workers who lost jobs, and young people looking for new jobs, remained unemployed or left the labor force rather than accept the jobs that were available. High minimum wages may also have prevented the absorption of low-skill workers.

One solution to unemployment, if this story is correct, is to allow for lower wages for less-skilled workers and to limit the amount or duration of unemployment benefits. This forces workers to take whatever jobs are available. To an extent, the United States has followed this approach and created millions of jobs for those workers, including immigrants, who have limited education or skill levels. But creating only low-wage or low-skill jobs is not what happened in the United States. The Council of Economic Advisers (1999) analyzed the nature of the jobs created in the United States between 1993 and 1999 and found that eighty one percent of the job growth was in industry/occupation categories paying above-median wages. New technologies and economic change create good jobs in large numbers, including the roughly 1.5 million additional jobs in IT service industries in the 1990s.

There has been much written on the importance of labor market flexibility. Many are aware in Europe that the introduction of new technologies and an accelerated pace of change reinforce the need for labor market flexibility. Actually bringing about change is a different matter. Chancellor Gerhard Schroeder spoke recently about labor market flexibility and said, as reported in the Financial Times of July 13, 2001, page 2: "We don't need an American-style labour market because we believe a higher level of [job] security and certainty is right."

- It is not so clear, however, how much security and certainty the more rigid European labor market has really provided. On the contrary, labor market flexibility, combined with product market flexibility and competition, are consistent with, in fact essential to, a fullemployment, high-productivity economy. The fears about job loss associated with competition and new technologies are exaggerated. After all, there has been no shortage of jobs in the US economy. The period of rapid productivity growth in the late 1990s coincided with declining unemployment and faster real wage gains than had been seen for many years. What cannot be guaranteed is that workers will be able to hang onto the same jobs they have now. 
Problems on the Demand Side. The discussion of other countries has been one-sided in its focus on structural supply-side issues. Clearly, for Japan to resume solid growth it will have to solve its financial crisis and generate sustained growth in aggregate demand. ${ }^{21} \mathrm{I}$ do not dispute the importance of solving Japan's financial problems. But the emphasis on structural problems here is deliberate. After all, Japan worked more hours per capita than the United States in 2000, and had higher capital intensity, ${ }^{22}$ so the fact that it produced only 74 percent of the output gives a pretty clear indication that it has a serious structural productivity problem, along with its financial crisis.

In fact, the financial crisis itself is linked to the structural problems. Misallocation of capital is an important structural issue that Japan must face in order to improve the productivity of the economy. Misallocation of capital is an important reason why loans have gone bad and the financial institutions are so troubled.

Japan has a particularly difficult problem to face, since major structural reforms could undermine confidence and weaken consumer confidence and consumption demand (although investment opportunities can be opened up). Japan should see itself as a transition economy, whose economy may have to get worse before it gets better.

For Europe, the demand side is important also. The fact that the European Central Bank follows a restrictive monetary policy does not help Europe grasp the benefits of the new economy. Moreover, the focus on structural problems may serve as an excuse for the central bank to continue its policy bias. But that does not mean the structural problems are not there. Monetary policy by itself is not the answer to sustaining more rapid growth in Europe. Ireland may provide an instructive example for Europe. This country has followed a path of openness, international investment and economic change and sped past the large European countries in recent years, even though it is a member of the Euro area. Per capita GDP in Ireland in 2000 was 81 percent of the US level, up from 43 percent in 1986. It is now well above the EU average. Ireland encouraged best-practice companies from around the world to invest in its economy and does not force them to conform to local norms.

Conclusions on the United States, Europe, and Japan. Looking at other countries has reinforced the findings from the earlier analysis of the US productivity acceleration. Certainly, growth in the United States has benefited from the large and dynamic high-tech sector. This sector in the United States had first-mover advantages and US companies have dominated major high-tech market segments. But as Wang, DEC, WordPerfect, and even IBM have discovered,

\footnotetext{
${ }^{21}$ See Kuttner and Posen (2001) and Bergsten, Ito, and Noland (2001).

22 The capital intensity data is for 1999, from McKinsey Global Institute (2000).
} 
first-mover advantages do not guarantee dominance indefinitely. Competitive intensity in ITusing industries drives the demand for IT and spurs its growth and innovativeness. Moreover, any country can purchase high-tech products; even if it does not make them.

- The challenge for Europe and Japan in taking advantage of the new technologies is to allow economic evolution to take place. This is not a new challenge, but has become of greater importance as the pace of technical change has quickened.

\section{THE NEW ECONOMY, WAGES, AND THE INFLATION- UNEMPLOYMENT TRADEOFF}

In this section I take up a new topic, turning the focus back to the US economy. I will look at the labor market, specifically at real and nominal wages and the relation between unemployment and inflation. Real wages are obviously important, strongly linked to living standards. But the interest in real wage growth goes beyond this in two ways. First, the behavior of real wages gives an independent reading on the extent and nature of the productivity acceleration. Second, the fact that nominal wage increases do not respond immediately to an acceleration of the productivity trend, provides one explanation, although not the only one, of why the unemployment rate fell so low in the 1990s without pushing up inflation.

Real Wages and Productivity. Both in theory and in historical experience, there is a link between the trend rate of productivity growth in the economy and the rate of change of real wages. This link is not a simple one, however.

In the special case of a one-sector growth model with a Cobb-Douglas production function and competition, the rise in average labor productivity is always equal to the rise in marginal productivity and hence the real wage. In practice, over the period 1959-73 the rate of real compensation growth was 2.54 percent a year, very close to the rate of labor productivity growth at 2.66 percent a year. ${ }^{23}$

The growth of real wages over time can diverge from the growth of overall productivity in a model with more than one sector. Specifically, with a two-sector Cobb-Douglas model (consumption goods and investment goods), it is simple to show that consumption real wages, defined as nominal wages deflated by consumer prices, will increase over time only to the extent that labor productivity rises in the consumption goods sector. The period of the 1970s and 1980s

\footnotetext{
${ }^{23}$ Nonfarm business sector, Bureau of Labor Statistics.
} 
illustrates this point since this was a time when consumption real wages grew very slowly indeed, even though aggregate labor productivity was growing at about 1.4 percent a year. Robert Lawrence and Matthew Slaughter (1993) and Barry Bosworth and George Perry (1994) argued that the real wage stagnation was largely the result of a change in the terms of trade between what workers produce and what they consume. A gap opened up between real production wages and real consumption wages.

Real wages are affected further by commodity prices. In particular, real wages fall when there are supply shock increases in energy and food prices. This finding is related to the above result and could in principle be studied in a three- or four-sector model. The intuition is clear enough, however. A sharp rise in energy prices imposes a tax on consumers that shows up as higher profits for energy producers, including OPEC. Workers pay that tax in the form of a reduction in their real consumption wages. Declines in real wages were evident in the food and energy shock period of the 1970s.

The final property of average real wages is that they display only a slight cyclical pattern. When the economy fluctuates as a result of variations in aggregate demand, there is a response of nominal wages, but only a small pro-cyclical pattern to movements in average real wages. ${ }^{24}$

Table 5 shows the growth of real wages over the periods 1978-95 and 1995-2000, using three wage series (total compensation, average hourly earnings and the ECI) and two price deflators (the Consumer Price Index U-RS [CPI] and the chain price index for personal consumption expenditure [PCE]). For both price indexes food and energy prices are excluded to abstract from their impact on wages. The results are striking. Using the PCE, the acceleration of real wages after 1995 is 1.92 percentage points for total compensation and 2.52 for average hourly earnings. Using the CPI, the accelerations are a little smaller, 1.50 for total compensation and 2.10 for average hourly earnings. ${ }^{25}$

The Employment Cost Index is a different type of wage measure than the other wage series. It abstracts from mix effects among industries and jobs. To the extent that the strong economic performance of the 1990s resulted in an upgrading of the mix of jobs, we would expect less acceleration of real wages measured by the ECI. And that is indeed the case, although the increased growth rate is still quite strong, up 1.28 percentage points for the PCE and up 0.92 percentage point for the CPI.

\footnotetext{
${ }^{24}$ According to Abraham and Haltiwanger (1995), "To sum up, correcting for all of the measurement problems, estimation problems, and composition problems does not lead to a finding of systematically procyclical or countercyclical real wages." They do note, however, that "the cyclicality of real wages is not likely to be stable over time."

${ }^{25}$ As a base-weighted index with a fixed market basket, computer prices, or indeed any rapidly declining price, has effectively dropped out of the CPI by the late 1990s.
} 
How would we expect real wages to behave following an acceleration of productivity? The key issues here are, first, we would not expect the cyclical component of the productivity acceleration to affect wages much, since traditionally real wages have not responded to demand cycles. And second, since most of the impact of the MFP acceleration in the high-tech sector appears in the prices of producer goods, one would expect only a small fraction of the high-tech MFP to show up in consumption real wages (especially for the CPI adjusted figures, see footnote 25).

Comparing these predictions with the results presented in table 5 is pretty startling. Total compensation deflated by the chain-weighted PCE index seems the better choice to compare with productivity (which is also a chain index). The acceleration of real consumption wages was generally even larger than would be predicted from the acceleration of productivity. ${ }^{26}$

Conclusions on Real Wages. The real wage data support the idea that there was a structural acceleration of productivity with a substantial impact on the sector of the economy producing consumption goods and services. Workers' average real consumption wages did much better after 1995 and any explanation of what happened over that period needs to be consistent with this fact. ${ }^{27}$

The Shift in the Unemployment-Inflation Tradeoff. A simple way to express the shift in the unemployment inflation tradeoff is to look at the "misery index," the sum of the unemployment and inflation rates. Table 6 shows the value of the index for selected periods, starting with the original recipe index, overall unemployment plus the CPI. Also shown are some variants: the first alternative uses unemployment plus the core CPI measured on a consistent basis over time. The second alternative measures inflation with the core PCE deflator. The overall story is pretty much the same regardless of the adjustments made.

\footnotetext{
${ }^{26}$ Suggesting that there may have been some positive effect of the cycle on real wages. Unraveling the cyclical pattern of wages is harder than I have said. Average wages, such as those shown here, are affected by the fact that in booms low-skill and low-experience workers enter the workforce, bringing down the wage average. One could "correct" for this problem by adjusting up the acceleration after 1995. However, one would then adjust this correction away again, as reflecting a cyclical effect. See Abraham and Haltiwanger (1995) for a discussion of this issue.

${ }^{27}$ Including food and energy reduces the wage acceleration by 0.37 percent a year with the CPI as a deflator. The rate of wage growth after 1995 remains below the rate of productivity growth. The adverse terms of trade effect identified by Lawrence and Slaughter, and Bosworth and Perry is still there. Productivity growth in the producer goods industries is faster than in the consumption goods industries.
} 
- The misery index in the late 1990 s was a throw back to the 1960 s and a sharp departure from the stagflation periods of the 1970s and 1980s. This section will explore the reasons for this favorable experience and the extent to which it is linked to other aspects of the new economy.

A big part of the unemployment/inflation story over the postwar period, of course, has been supply shocks. The 1970s and early 1980s looked so bad because food and energy prices took off and pulled up overall inflation. To fight the inflation, monetary policy restrained demand and the result was high unemployment. By contrast there were some very favorable supply shocks in the 1990s that went in the opposite direction. Robert Gordon has developed the supply shock model over the years and in his 1998 study he points out that declining energy prices through 1998, a sharp decline in the rate of increase of health care costs helped hold down unit costs and a strong dollar pushed down import prices. As energy and health care prices moved up again in 1999 and 2000, there was some upward movement in wage and price inflation. Supply shocks do not seem to be the whole story, however. Even after taking account of these shocks there appears to have been a favorable shift in the tradeoff in the 1990s.

There is no shortage of explanations in the literature for this phenomenon, but before turning to these, it is worth noting one objection to the whole exercise. Econometricians such as Christopher Sims (1999) and James Stock (1998) question whether there is any systematic relation between inflation and unemployment. They note that in unrestricted regressions, the unemployment rate is a poor predictor of inflation. And as many observers have pointed out, once you go outside the United States, the Phillips curve relationship looks even more unstable or nonexistent. While recognizing the basis for the Sims-Stock viewpoint, I still find it helpful to look at the unemployment and the inflation stories together. ${ }^{28}$ However, there is a legitimate question that flows from their viewpoint. Some part of the decline in unemployment may have been the result of structural changes within the labor market, so that a given pressure of demand in the economy is associated with a lower unemployment rate.

Productivity and the Shift in the Tradeoff. There is a simple and parsimonious explanation of the 1990s shift in the tradeoff that relates directly to the analysis above. Prior to

\footnotetext{
${ }^{28}$ The fact that unemployment is not a very good forecasting variable does not invalidate the concept of an unemployment inflation tradeoff. Unemployment is a lagging indicator of demand fluctuations and may be unsuitable as a forecast variable. And both inflation and unemployment may be affected strongly by other factors. In other countries, such as Europe, structural problems have played a large role in the rise of unemployment in the 1970s and 1980s, as I noted above. But even there, the tradeoff can emerge. Stronger demand has both lowered unemployment and raised inflation in Europe in the late 1990s.
} 
1973 productivity growth and real wage growth were rapid. Then both slowed sharply and this was followed by an extended period of high unemployment and high inflation. Then productivity and real wages accelerated again in the 1990s and there was an inward shift of the tradeoff. This simple and appealing view has been proposed by Alan Blinder (2000), the Council of Economic Advisers (2000) and Laurence Ball and Robert Moffitt (2001).

The argument is generally given as follows. Workers have some level of wage aspirations. They expect their real wages to increase by some amount each year, with the amount determined by the past history of real wage increases. Nominal wage increases are then equal to the expected rate of price increase plus the real wage aspiration. If the equilibrium rate of real wage increase falls because of a decline in productivity growth, workers do not accept this initially and push up nominal wages in a fruitless attempt to achieve higher real wage increases and the result can be higher unemployment and lower GDP. The process works in reverse for productivity acceleration, as workers are not expecting or aspiring to the real wage increases that they end up receiving. Implicit in this story is that the resulting shifts of the tradeoff, in or out, are temporary. Once workers' aspirations catch up to the new reality, the old relationship should reemerge.

I have some difficulty with the story around this hypothesis. The description of workers' aspirations seems more applicable to the European labor market with strong unions and centralized wage negotiations than to the United States, where unions are only a tiny fraction of the workforce. But despite this reservation, it seems highly plausible that productivity has played a role in the favorable tradeoff of the 1990s.

It is a robust result that there is substantial inertia in wage setting, where the rate of nominal wage increase depends on past wage and price increases. Since labor costs are such a large fraction of total costs, wage inflation feeds directly into price inflation. The idea of a wageprice spiral holds up, whether or not there is solid economic theory behind it. In this case, any change in trend productivity growth will immediately impact the wage-price process. Wage inflation in a given period is largely predetermined and so an increase in productivity growth will reduce the rate of increase of unit labor costs. Some part of this may translate into higher profit margins, but with competition, some part will also yield lower price inflation. Lower price inflation then holds down wage increases on the next round. The productivity acceleration is a natural explanation, combined with reinforcing monetary policy, for why inflation continued to fall during such a strong expansion. 
Structural Reasons for Lower Unemployment. Lawrence Katz and Alan Krueger (1999) point out that the decline in unemployment in the 1990s was associated with a marked shift in the Beveridge curve, the relation between unemployment and vacancies. ${ }^{29}$ Thus, one possible reason that inflation remained tame at such low unemployment rates is that low unemployment was no longer signaling the same tightness in the labor or product markets as in previous periods.

Katz and Krueger identify four factors that may have lowered unemployment. The effect of two of these they are able to estimate fairly precisely. Demographic shifts have reduced the fraction of the workforce that is in unemployment-prone groups. Basically, the end of the baby boom has resulted in a smaller cohort of high unemployment teens. This reduced the unemployment rate by 0.4 percent. There is a long history of such demographic adjustments, going back to the work of George Perry and this conclusion seems solid.

The second factor is the rise in the proportion of the population incarcerated. Those held in prisons or jails are largely young males, many of whom would be unemployed if they were part of the labor force. Katz and Krueger judge that this reduced the unemployment rate by 0.17 percent. This seems plausible, although not a very important factor. ${ }^{30}$

The two other sources of decline in the unemployment rate are, first, that the growth of temporary help agencies and workers has helped workers who want to continue working while looking for a new permanent position. And, second, that the decline in unionization and the increase in competitive intensity in the economy have made it harder for workers to push for wage increases. Katz and Krueger argue that it is impossible to estimate the quantitative impact of these two factors with any precision. At a maximum, they say, they could account for 0.1 percent and 0.4 percent declines in unemployment respectively.

Work by Jessica Cohen, William Dickens, and Adam Posen (2001) has proposed an alternative structural explanation for the favorable unemployment shift. Unemployment is a search and waiting process. Workers look for jobs or just wait for suitable jobs to open up. There is of course an extensive job search literature that has explored this process and the economic decisions behind it. Cohen, Dickens, and Posen suggest that there have been two important shifts in the labor market that have altered the optimal search behavior. The first has already been

\footnotetext{
${ }^{29}$ There is some uncertainty about the nature of this shift as there is no ideal measure of job vacancies. Katz and Krueger use help-wanted advertising and make use of the adjustment of the help-wanted index that Katherine Abraham made through 1985. One can question whether help-wanted ads are playing the same role as a source of workers today that they did in 1985.

${ }^{30}$ Gary Burtless points out (1999) that there is a related structural change going in the opposite direction. There has been a substantial decline in the number of young men in the armed forces. There is an inherent danger in searching for reasons why unemployment has fallen. One may ignore similar reasons why unemployment may have increased.
} 
identified--workers can more easily take temporary jobs while continuing to search for a permanent job. The second shift is that the return to waiting and searching has declined for many workers.

Historically, they argue, there were many jobs that carried a substantial rent to the workers that held them. Unionized wage setting or institutional wage setting in large corporations meant that workers that found employment at General Motors or IBM could expect to earn a much higher wage than if they worked in a similar job in a small or non-unionized company. One manifestation of this was that strong and persistent industry wage differentials emerged in empirical analyses (see for example Lawrence Katz and Lawrence Summers [1989]). Industries with strong unions or dominated by large companies would pay persistently high wages, controlling for observable characteristics of the workforces. Any unemployed worker that had a chance of gaining or regaining one of the high-rent jobs would have an incentive to remain unemployed. $^{31}$

Changes in human resource management practices, argue Cohen, Dickens, and Posen, have reduced the availability of high-rent jobs. They find evidence for this in a large reduction in inter-industry wage differentials. They identify the reason for this in a way that links to the new information economy. Rapidly changing technology and increased globalization have increased competitive pressure in the economy, forcing companies to eliminate excess costs. Eliminating rents paid to low-skill workers is a response to this pressure. This can occur through the adjustment of wage rates within companies or through outsourcing activities that are not part of a company's core competence. I would argue also that the overall widening of the wage distribution and the increase in the return to education and skill are consistent with this view. In the past, wages within companies were influenced by equity considerations. Today, workers get their marginal products - the labor market is more efficient. Unfortunately this results in a much wider wage distribution. ${ }^{32}$

The changes described by Cohen, Dickens, and Posen did not start in the 1990s, but in their view, this is in their favor. They point to the Beveridge curve, which shifts in the $1980 \mathrm{~s}$, and

\footnotetext{
${ }^{31}$ This is the same as the Harris-Todaro model of unemployment in developing countries, where workers crowd into the cities and remain chronically unemployed in hopes of getting a high-rent job.

${ }^{32}$ There is an interesting question as to how this view of the greater efficiency of the labor market relates to the view that workers may be more nervous about their jobs and that is why they are less pushy about wage increases. Employers threaten to outsource the activity of any group within the company that is not cost efficient. Basically, the two ideas seem to fit together pretty well. But there is the possibility that once all rents have been taken out of the system, workers will be less nervous. Losing a job is not so bad because a worker can expect to earn the same amount in the next job.
} 
then again after 1994. I am not so sure. At the end of the 1980s expansion, wages and core inflation started to rise when the unemployment rate fell below 6 percent. This was close to estimates of the Non-Accelerating Inflation Rate of Inflation (NAIRU) made from earlier periods. The shift in the relation between capacity utilization and unemployment occurred in the 1990s.

Conclusions on the Unemployment Inflation Tradeoff. A major reason why the misery index was so much better in the 1990s is that the economy did not face the severe supply shocks of the 1970s and early 1980s. Over and above this, the favorable behavior of unemployment and inflation in the 1990s expansion is seen as an implication of the new economy-appropriately so. The revival of productivity growth has boosted real wages and resulted in at least a temporary shift in the tradeoff. The timing is right and we know what happened after 1973 when productivity slowed. Strong productivity growth and favorable price shocks allowed the Fed to steer inflation lower in the 1990s while maintaining strong demand in the economy. The strong productivity kept going through 2000, even though the supply shocks turned around.

On the unemployment side, the case for some structural improvement in the labor market is good enough to suggest sustainable unemployment has fallen below the 6 percent that was estimated earlier. The Clinton CEA estimated the NAIRU or sustainable rate of unemployment to be in the 5 to 5.5 percent range. Much of this reduction is the result of changed demographics and the remainder from improved efficiency and a shift from institutionally determined wages to market determined wages.

Over the next few years, however, the impact of supply shocks or structural labor market effects will be overwhelmed by the impact of the productivity trend. If the productivity trend continues to be strong, monetary policy should sooner or later be able to ease the economy back onto a track of low inflation and moderate unemployment. If, on the other hand, the productivity trend falls back to 1.5 percent, the inflation-unemployment situation will look less attractive.

\section{THE IMPLICATIONS FOR THE STOCK MARKET, CONSUMPTION, AND THE INFLOW OF CAPITAL}

The arrival of the new economy has coincided with a very large increase in the value of corporate equities, a rapid rate of increase in consumption and a large increase in the inflow of capital to the United States. To what extent are these phenomena linked and linked to the new economy. 
Through 1999 the performance of the US stock market was extraordinary. An investment of $\$ 100$ in December 1989, with all dividends reinvested would have been worth nearly $\$ 500$ at the end of 1999 . Adjusting for inflation still yields a total return of 250 percent. The growth in the market from 1995 to 1999 was even more remarkable, with a total real return of 189 percent, or 24 percent a year on average. Previous bull markets (1921-28 or 1932-36) came after severe stock market downturns, but the post 1995 bull market came after strong performance for 10 years prior to $1995 .^{33}$

One explanation for the run up in the market is that it was a speculative bubble, the result of a fad, as Robert Shiller (2000) puts it. And given the weakness in markets since then, especially among technology stocks, that explanation has a lot of force. But aside from the craziness in the NASDAQ, the surprising thing perhaps is not how weak the market has been in the past year or so, but how resilient it has been. The market value of publicly held corporate stock reached \$17.5 trillion in December 1999, hit a monthly peak in August of 2000 at $\$ 18.9$ trillion and had fallen to $\$ 15.5$ trillion in April of $2001 .^{34}$ This decline has created a feeling of vertigo in many investors, but after all the market value was a mere $\$ 7.4$ trillion in January of 1996 ! In mid 1999 when the market was also in the range around $\$ 15.5$ trillion everyone was counting their winnings. Even if air keeps coming out of the bubble for a while yet, there is still the likelihood that the increase in market value is reflecting changed fundamentals as well as some irrational exuberance.

The Risk Premium. One explanation of the rise in the market is not linked directly to the new economy, namely a reduction in the risk premium. Over the roughly 200 -year period 1801 to 1999 the real return to stocks was 7.1 percent and the real return to bonds was 3.4 percent. ${ }^{35}$ If the gap in returns is interpreted as a risk premium, the premium was 3.7 percent. Over the 1949 to 1999 period, the return to stocks was 8.8 percent and to bonds 1.5 percent for a risk, with an implied risk premium of 7.3 percent. A risk premium of this magnitude seems quite out of line with common sense or the behavior of individuals in other contexts. Thus some part of the increased value in stocks may be the result of a realization by investors that stocks have earned a much higher risk-adjusted return than bonds. With dividend price ratios of around 1.5 percent in 1999 and earnings price ratios of around 3 percent, the market may simply have eliminated the risk premium.

\footnotetext{
${ }^{33}$ The market was very weak in the 1970s and early 1980s, however.

34 These figures exclude the Amex.

${ }^{35}$ The figures in this section are from the Economic Report of the President (2000), which used the analysis of Jeremy Siegel (1994).
} 
Explaining why this happened in the 1980 s and 1990 s is trickier. One possibility is that the availability of stock mutual funds and the incentives for $401 \mathrm{Ks}$ have made it easier and cheaper for individuals to own a diversified portfolio of stocks. A second view is that the impact of the stock market crash of the 1930s has faded, particularly as a new generation of wealth holders has emerged.

There are difficulties with the risk premium as the explanation of the rise in the market. First, in a general equilibrium context it is not clear how a reduction in the risk premium would play out. In a closed economy with a saving rate that is invariant to the interest rate, the impact of a fall in the risk premium would be a rise in the risk free rate of interest, as the return to stocks would be the return to corporate capital, which would be unchanged. In an open economy or one with a very responsive saving rate, the impact of a decline in the risk premium would be a very large increase in the equilibrium capital stock. ${ }^{36}$ Now there was a surge in investment in the 1990 s, but the increase in the capital stock is not nearly enough to bring the return on corporate tangible capital down to the level of the risk-free interest rate. With a Cobb-Douglas production function and a capital share of one third, the capital labor ratio would have to increase by a factor of 2.8 to cut the marginal product of capital in half. Perhaps capital-labor substitution is not as great as Cobb-Douglas, and presumably it would take some time to reach the new equilibrium, but even so it is hard to make the arithmetic come out plausibly.

The second difficulty with the risk premium argument is that Wall Street analysts were not arguing to investors that they should buy stocks despite a reduction in expected returns because stocks are safer than people thought. Nor did most of the holders of stocks seem to view their decision as based on a changed view of the risk premium. The market gyrations in the past year or so, surely must have reminded people that stocks are risky. Reinforcing this impression is the fact that the increase in the stock market induced a very large increase in consumption and a decline in the conventionally measured saving rate. Figure 2 illustrates the strong relation between the value of the market and the run up in consumption. If US households as a group had believed that there was no increase in the ability of corporations to generate returns, there was no reason to expect a higher future income stream that would allow a higher current or future level of consumption. Some households may have found their corporate wealth increased, but other households faced a much higher price to purchase corporate assets in the future. The behavior of consumption suggests investors expect higher returns.

\footnotetext{
${ }^{36}$ Robert Hall (2000) makes essentially this argument.
} 
In summary, greater ease of acquisition of stocks and a greater willingness to hold risky stocks may well be a contributing explanation of the rise in market valuations. But it is hard to see these as the whole story.

Intangible Capital. The optimistic interpretation of the rise in corporate market value is that it indicates an increase in the stock of intangible capital. Lowell Bryan et al (1999) have argued that a series of changes in the world economy have allowed many companies to drastically increase their market valuations relative to their book values. These changes included a reduction in barriers to trade and international investment, the reduction in transaction or interaction costs associated with advances in computing and communications technologies, and the realization by corporations that they can follow a globalization strategy that emphasizes intangible rather than tangible investments. Companies define their core competency and then globalize this asset, rather than building their complete business overseas from the ground up.

These authors describe the investments in knowledge, people, relationships and reputation, companies use to create intangible assets in the form of intellectual property, talent, networks and brands. The concept of intangible capital is not something dreamed up by economists, it is an idea that has become central to actual business strategies.

Robert Hall (2000) has also linked the rise in the stock market to the increased importance of intangible capital, and he ties this directly with the information economy, christening the intangible capital "e-capital." Corporate investment and hence profits have been substantially understated in the 1990s, argues Hall, because the acquisition of e-capital has not been measured. Hall points out that the valuation of many large companies bear very little relation to the amount of tangible capital held by these corporations.

The obvious issue about this view of the rise in market valuation is that the proof or refutation of this idea is out there in the future. One can tell an internally consistent story about the rise in corporate market valuations, based on the accumulation of intangible capital that will pay off in higher returns, and presumably, greater productivity growth in the future. In fact one can argue the surge in productivity and corporate profits after 1995 is a sign that this was indeed happening until $2000 .{ }^{37}$ But the real question is unanswerable so far: will the future stream of profits justify the greatly increased valuations?

\footnotetext{
${ }^{37}$ In Baily (1981) I argued that the post-1973 slowdown of productivity was linked to the weakness in the stock market, both phenomena reflecting an increased rate of obsolescence of capital. Greenwood and Jovanovic (2000) make a related argument, suggesting the decline in the value of old capital was linked to the impending arrival of the new economy, which promised to devalue the old capital.
} 
The Inflow of Foreign Capital. Apparently foreigners believe, just like US investors, that the new economy has increased the expected future return from US corporate capital. Figure 3 shows the rapid increase in the net inflow of foreign capital into the United States, heavily concentrated in direct foreign investment and securities. ${ }^{38}$

As a consequence of the foreign appetite for these US investment opportunities, the portfolio of assets held by foreigners has shifted into equities and direct ownership of US companies. These two classes of investment constituted roughly 50 percent of all assets held by foreigners in 1999, up from around 30 percent in 1990.

The desire of foreign companies to buy into the United States does not mean they are just buying high-tech or IT companies. The new economy in the United States is apparently making traditional industries attractive too. The breakdown of direct foreign investment by industry shows increased investment in high-tech sectors such as electronic components, computer services and telecom. But there was also a large increase in investment spread throughout a range of different industries, including traditional manufacturing industries and heavy IT users such as insurance and financial services. ${ }^{39}$ Equity investment may have been more heavily skewed to the tech sector, but I do not have a breakdown of that capital inflow.

Conclusions on the Stock Market and the New Economy. It is unlikely that the whole idea of a new economy would have entered the popular imagination except for the fact that the stock market performed in such an extraordinary fashion over the past 15 years, and particularly over the 5 years through mid-2000. And there are some good reasons to attribute at least part of the market's rise to the same forces of IT and globalization that have driven the strength on the real side of the economy. The market and the new economy of the 1990s seem inevitably and strongly linked. Without the performance of the IT sector and the growth in productivity, it is hard to see the rise in market value having continued so strongly in the second half of the decade. Without the rise in market value it is hard to see the boom in investment and consumption running as strongly as they did. Without the draw of rising corporate values, it is hard to see capital flowing into the United States as it did.

Mindful of Shiller's warnings, however, the chances of a substantial weakening of the market remain real, particularly if productivity trend slows and profits remain weak.

\footnotetext{
38 The "other private assets" category includes bank loans.

${ }^{39}$ See the table at http://www.bea.doc.gov/bea/di/fdi-ind.htm
} 


\section{THE NEW ECONOMY DOWNTURN}

For a time one heard arguments that the business cycle was dead in the new economy, but the sharp slowdown of recent quarters has ended that debate in a hurry. Now we seem to hear the opposite; that the economy is stuck in an extended period of stagnation with little hope of speedy recovery. The pendulum of opinion has swung quickly. More time must elapse before we can draw the picture of the latest cycle, but it is helpful to review what we know about the downturn so far against the backdrop of previous cyclical episodes.

After World War II, the relative stability of the US economy, compared to the extreme volatility of the prewar economy was a welcome surprise and was seen as a result of a more stable, service-centered economy and as a tribute to a more stabilizing policy environment, including the effects of the automatic stabilizers. ${ }^{40}$ Recent literature has focused on the postwar period, exploring the question of whether stability has either gradually or abruptly increased. Margaret McConnell and Gabriel Perez-Quiros (2000) identified a break point in the volatility of the economy as having occurred in the mid-1980s. Olivier Blanchard and John Simon (2001) take a somewhat different view of the postwar period, arguing that instead of a one-step reduction in volatility in the early 1980 s, there has been a steady reduction in volatility that was broken in the 1970s and 1980s by inflation shocks. Blanchard and Simon argue that since there has been a long trend of volatility decline, it cannot be attributed only to the new economy. In decomposing the sources of the decline they work from the demand-side components, rather than looking at industry sectors. They conclude that in the early postwar period there was a reduction in the volatility of government spending (fiscal policy became a smaller source of instability). And that "[m] ost of the decrease in overall volatility can be traced to a decrease in the volatility of consumption and investment" (page 20), particularly consumption. Looking at the correlation among different sources of volatility, they document the shift in the relation between inventories and sales. An important factor in the decline in output volatility in the 1980s is that inventory investment has become counter cyclical — so the new economy may well have played a role in the continued decline in volatility in the past 15 years. Changes in the composition of output, they find have little to do with the decline in volatility.

Figure 4 shows the rate of growth of GDP over the postwar period, and the drop in volatility since the mid-80s is evident.

${ }^{40}$ See for example, Burns (1960) and Baily (1978). 
The Current Slowdown Against the Backdrop of Greater Stability. The US economy grew at 5.3 percent from the middle of 1999 to the middle of 2000. Over the next three quarters GDP growth has averaged only 1.5 percent, a drop of 3.8 percentage points in the rate of growth. Table 7 compares this decline to comparable periods in the nine actual recessions since World War II. The table shows the rate of growth of GDP in the four quarters up to and including the peak, the three quarters following the peak and the difference between the two growth rates. The current slowdown is not a recession, but measured in terms of the drop in growth, it ranks close to the middle ( $6^{\text {th }}$ out of ten) compared to prior recessions. Moreover, coming after ten years of GDP growth, and four years of growth at over 4 percent (with 1996 at 3.6 percent), there was a shock value to the drop in growth. The unusual feature of the current slowdown was how fast the economy was growing before it hit the wall. It grew faster than during any of the four quarters prior to earlier recessions, except for 1953.

How different is this slowdown from previous downturns? Table 8 shows the contributions of different components of GDP to the slowdown. The BEA reports for each quarter the contribution of each component of GDP to the growth of GDP. I computed the average contribution of each component for the four quarters up to the peak and the average contribution for the three quarters after the peak. The decline in the contribution of each component as a percent of the total decline in GDP growth, then reflects the percentage contribution of each element of GDP to the total growth slowdown. The table looks at all ten periods of slowdown or recession. Aside from nontrivial rounding errors, the contributions add to 100 percent.

The overall pattern of contributions, revealed by the mean or median values, is not a surprise. Inventories generally have a large role in downturns. They are small relative to the total economy, but highly volatile. Consumption makes about the same contribution, not because it is so volatile, but because it is so large. It includes consumer durable purchases, which are quite cyclical. Equipment investment is also a large contributor and total investment is actually the largest overall contributor to growth slowdowns, adding the two columns. The negative sign on net exports indicates that this component typically helps support growth during a slowdown, as imports fall more than exports, or exports may grow more rapidly. Government consumption is not much of a stabilizer (taxes and transfers would be), except in 1960. It was a destabilizer in 1953.

The contribution of inventories to the 2000 slowdown was above average for the whole period, but not out of the range compared to 1981 and 1990. The contribution of equipment investment and software to the slowdown is substantial but not much above average in terms of postwar recessions. The reason the role of equipment investment in the current episode looks so 
important is that this part of GDP has not been a major driver of recessions since the 1960s and has contributed only a small share to the two most recent slowdowns, in 1990 and 1981. The large contribution of equipment investment in the current slowdown comes against the backdrop of much less volatility in this component in the past thirty years.

The contribution of other investment is unusual. Other investment actually added to growth marginally more after 2000 QII than before. This reflects the fact that when the Fed was raising rates, this dampened the housing sector in early 2000, before the rest of the economy slowed. Then once the Fed started its aggressive downward moves in rates this has helped keep the residential housing market robust. This component of the slowdown is consistent with monetary policy as a stabilizer, cooling the economy off when it was running to hot and warming it up when it is running too cold.

Overall, the decomposition of this growth slowdown reveals a pattern that is typical for the postwar period as a whole. It was concentrated slightly more than average in inventories and equipment and software. (The just released figures for 2000QII show a sharp drop in investment but an easing of the inventory adjustment).

What is perhaps surprising is that new economy inventory management systems did not seem to prevent a classic inventory cycle. High-tech companies got stuck with a ton of excess inventory. There is no doubt that improvements in supply chain management have occurred, as evidenced by the rapid productivity growth in wholesale and retail trade, the decline in the inventory to sales ratio, and the change in the correlation of sales and inventories. But the impact of a sharp and unexpected slowdown in growth overwhelmed the impact of better information. In fact, perhaps the improved access to knowledge actually caused a quicker and broader response of inventories to the slowing of the economy. Once every one realized growth was tumbling, they all scrambled to avoid being stuck with too much inventory. The response to falling sales was not spread out over time, but concentrated. Another characteristic of the information economy may be important here also. Since prices of high-tech equipment fall so fast (the equipment becomes obsolete quickly), holding excess inventories is very costly indeed. Working off excess inventories in the high-tech sector, where the own rate of interest is so high, had to be a major priority.

Downturns are intrinsically hard to call and the consensus forecast rarely catches them. However, in this downturn, they were pretty wide off the mark. The Blue Chip consensus forecast for 2001 peaked in October 2000 at 3.5 percent, and then dropped to just over half that level by early 2001. Information technology has not improved our ability to see the economic future. To the extent that CEOs in the early fall of 2000 were listening to their economic forecasters, they 
would not have been planning for such a dramatic growth decline. Late into 2000, it looked as if the economy was achieving a soft-landing.

The Moderate Impact of the Dollar and the Stock Market. Although the forecasters did not predict the extent of the slowdown, there was talk as early as 1999 of a hard landing scenario that was a matter of concern to policymakers and others. The scenario we worried about was one in which weakness in the US stock market would trigger a sharp reduction in the desired inflow of capital to the United States. Since the trade balance moves slowly, the actually inflow would have to continue and in order for that to happen, the dollar would fall sharply, particularly against the euro. Once that process started, both confidence and the stock market would then fall further. Monetary policy would find it difficult to respond, because of the impact of a falling dollar on inflation. Consumer spending would plummet with the fall in the market, and the loss of confidence.

Some pieces of this scenario did happen. The grossly overvalued NASDAQ collapsed, and the broad stock market has fallen by about 30 percent. Furthermore, consumer confidence did fall sharply in December. But so far at least, the rest of the pieces have not played out as feared. As this is written, the euro is trading around 90 cents, up from its lows, but still very weak. A fall in the growth of consumer spending has contributed to the fall in GDP growth, but spending on autos and houses has remained rather robust. The Federal Reserve has felt free to cut interest rates aggressively.

Even though the US economy has weakened, the relative attractiveness of the United States as an investment destination has not. Japan's economy shows no sign of pulling out of its decade-long stagnation. In fact, Adam Posen (2001) suggests that the Japanese financial sector is on the verge of collapse. Europe initially looked as if it would continue to grow and perhaps show more evidence of a supply-led, new economy expansion. But that hope has now faded and the forecasts for Europe are now tumbling, just as the ones for the United States did late last year.

While the weakness overseas has helped prop up the dollar and the US stock market, it is very much a two-edged sword. The strong dollar is hurting US manufacturing. A few years ago, the world rode out the financial crises and sluggish growth in Europe in part because the US locomotive was pulling the train. Right now, the United States could use help but is not getting it.

Conclusions on the Downturn. The US economy is in a downturn that through mid 2001 looks very much like the average postwar downturn in broad outline. Anyone who thought that the business cycle was dead has been disillusioned. Going forward, the United States typically recovers pretty quickly from recessions and so far this is not even a recession, so a pick up of 
growth within the next few quarters is probable. Most likely we will look back and see no strong implications of the new economy for cyclical volatility.

One issue that could change the optimistic view I have just expressed is if the productivity growth trend were to collapse. A second and unfores een concern that has suddenly arisen is that the terrorist attack in September could shake confidence and precipitate a recession in a global economy that is already shaky. At this time, policymakers around the world are moving forcefully to reassure people and ensure financial markets remain liquid. But the chances of a sharper or more prolonged slowdown have certainly increased. Certainly the robustness of the stock market is being tested.

I turn next to look at monetary and fiscal policy in a situation where there is uncertainty about trend growth.

\section{THE NEW ECONOMY, UNCERTAINTY, AND THE IMPLICATIONS FOR MACRO POLICY}

I have just noted that cyclical volatility in the US economy has been generally lower since the mid-1980s, and that the current downturn is not especially unusual. On the face of it, the uncertainty about the economic future faced by policymakers should be no worse than has been the case historically. When it comes to longer run uncertainty, however, the situation is very different. The new economy that emerged in the 1990s could generate rapid productivity growth for 20 years or more. Or we could go back to the days of sluggish productivity growth, weak tax revenues, and rising inflation. Uncertainty about the growth prospects for the next five or ten years are very great.

There was a traditional view of the economy that served policymakers well in the past as a guide to economic policymaking. Arthur Okun defined potential GDP, which was estimated to grow over time at a rate determined by the trend rate of increase in productivity and the increase in the size of the labor force. Both the productivity trend and the growth of the labor force were thought to be fairly predictable, and the NAIRU was thought to be stable. Potential GDP growth itself was therefore seen as predictable.

This view of the economy did not suggest short-term economic or budget forecasting were easy, quite the contrary. In any given year, the actual level of GDP might differ from the level of potential GDP, being above or below it. But in the simple Okun world, the uncertainty about the short term did not lead to exploding uncertainty over the longer term. As long as the growth of potential output was predictable, there might be one or two years where recession 
resulted in a deficit, but this would then be offset by a year or two of rapid GDP growth when the deficit would shrink or be eliminated. The uncertainties year by year were partially offsetting.

Unfortunately, over the past 25 years our ability to predict the growth of potential output and to predict the long-term fiscal position of the economy has been weak. There are long periods when the economy does not revert back to prior estimates of its potential GDP. The economy starts to do well and continues to do well, or it starts to do badly and continues to do badly. During the 1990s, and particularly in the second half of the decade, the economic forecasts were consistently too pessimistic. We kept thinking that the economy must slow down, bringing GDP back closer to our estimate of a stable path of potential GDP. And of course, the economy kept growing rapidly. In earlier periods, the errors were in the opposite direction. We know now that the trend rate of growth of productivity and GDP slowed after 1973. But careful forecasters at the time thought that potential output growth would return to the more rapid pace it had achieved for the 25 years prior to 1973 . The same mistake was made in the 1980 s for a different reason, when overoptimistic projections were made of the impact of tax cuts on potential growth.

In large part, the reason for these mistakes is the uncertainty in the productivity trend, which makes potential output growth harder to predict than we thought. But the problem is actually bigger than this for reasons that have emerged in this paper. Good news about trend productivity generates a virtuous cycle of good news about inflation, unemployment, budget surpluses, interest rates, the stock market, the dollar and investment. Once the ball gets rolling it gathers speed. Faster productivity growth lowers inflation and increases real wage growth. This improves the situation in the labor market and allows the economy to operate for an extended period with lower unemployment and higher GDP. The return to capital investment goes up, encouraging more investment, raising stock market prices, and continuing the strong growth.

On the down side, the pattern works in reverse. A return to slower productivity could unleash a cycle of problems that eliminated projected budget surpluses, in the absence of a policy response. Slower productivity growth would worsen inflation and weaken the dollar. It would lower real wage growth and trigger a worsening of the wage price spiral. And of course there would be less GDP and less tax revenue.

The Sustainability of Budget Surpluses. In January, the Congressional Budget Office projected that trend productivity would grow at 2.7 percent a year. They recognized that the cyclical growth slowdown would result in actual productivity growth below this level, but they still assumed a 2.5 percent growth rate over ten years - basically a continuation of the very strong trend of the late 1990s. In some other respects the CBO was relatively conservative in its 
economic estimates, so I am not saying that their predictions were out of line with the views of many economists at the time. But based on what we know now, the January estimate of a $\$ 3.1$ trillion on-budget surplus in the 10-year budget horizon was premised on a continuation of very good economic news. This is reinforced by the fact that $\mathrm{CBO}$ is pretty optimistic in its estimates of the revenues to be expected from their economics.

Since their baseline projection was made in January, several things have changes. First, $\$ 1.35$ trillion tax cut has passed. Second, in their August budget outlook CBO estimates that legislative changes will increase spending by approximately $\$ 400$ billion over the next 10 years, further reducing the projected surplus. Add to this the lower economic growth now projected and some technical changes that the CBO has made, and the $\$ 3.1$ trillion surplus projected in January is now reduced to $\$ 0.85$ trillion.

The August CBO budget projection is still based on rather an optimistic outlook, with labor productivity growth assumed to be 2.5 percent over the next ten years. If instead, growth were 2.0 percent over ten years, instead of 2.5 percent, still a pretty good performance, this would reduce real GDP growth relative to CBO's August projection. It would reduce revenues and the deficit over the period $2002-2011$ by about a $\$ 1$ trillion and bring the budget into deficit. ${ }^{41}$

And this is not at all a bad-news scenario. Suppose the productivity revival fizzles out. A specific reason for concern is that in the current slowdown investment in high-tech has fallen so hard. We have seen that a major contributor to the rapid growth of the 1990s was the boom in high-tech investment. The high-tech sector itself contributed directly to faster productivity growth, and the industries buying the equipment were able to increase their productivity. But it looks now as if there was significant overinvestment in this area, particularly in telecommunications. The high-tech sector is currently very weak and likely to remain so for a while and we may well not see a resumption of very high levels of investment for a while. Several economic forecasters are lowering their estimates of potential growth because of this fall in investment. Productivity growth was only 1.4 percent a year from 1973 to 1995 and a return to that level is not impossible.

In addition, the unemployment rate is rising and is likely to continue to rise. If productivity weakens, this will raise the possibility of stagflation, just as we saw in the 1970s when productivity slowed. A slowing of productivity means that unit labor costs increase faster, contributing to some combination of higher inflation or higher unemployment. The dashing of

\footnotetext{
${ }^{41}$ According to table B-1 of CBO's January Outlook, 0.1 percent slower GDP growth reduces the surplus by $\$ 244$ billion. A drop of 0.5 percent a year in nonfarm productivity translates into a decline of about 0.425 percent a year in GDP growth. \$244 billion multiplied by 4.25 yields about $\$ 1$ trillion.
} 
expectations about productivity growth would have an adverse effect on the stock market and investment and on consumer confidence and spending. And finally the scenario we started to worry over in 1999 could still happen if the inflow of capital slows and the dollar weakens sharply.

In short, if things start to go badly, there may be not just a minor shortfall in the budget estimates, there could be a major shortfall.

Conclusions for Budget Policy. I have previously outlined my reasons for favoring fiscal discipline over large tax cuts. ${ }^{42}$ First, if large on-budget surpluses do materialize, they should be used in part to address the long run deficit problems of Social Security and Medicare. The long run fiscal position of the federal government is not good, given that the baby boomers will soon be moving into retirement. Second, a large tax cut is particularly bad policy at a time when the United States is running a current account deficit equal to about 4.5 percent of GDP. We need to increase national saving, not decrease it over the next ten years. Third, while a stimulus to the economy is fine now, it will not be fine later. A tax cut shifts the mix of monetary and fiscal policy, raises interest rates, discourages housing and dampens investment and productivity growth. Even now it seems that long rates have not fallen in line with the decline in short rates that the Fed has induced. Fourth, the new economy emerged at a time of extraordinary fiscal discipline. Fiscal discipline did not create the new economy but it helped start the virtuous cycle going. Why change now? Fifth, the surplus projections, based on existing policy, may not be realistic on the spending side. Both parties agree that Federal spending should be controlled, but both parties also agree on the importance of a strong national defense and social investments in health, education and the environment. Spending over the next ten years may continue to decline as a share of GDP, but probably not as fast as assumed in the budget projections.

Over and above these reasons, today we face unusual uncertainty as we wait to find out more about the durability of the acceleration of productivity and GDP growth that took place in the latter 1990s. I remain optimistic about the economy and look forward to a return to solid productivity growth once recovery is underway. But the current risks in the budget forecast are mostly on the downside and sound budget planning should recognize these downside risks and should not use up surpluses we do not know we have and that may never materialize.

\footnotetext{
42 Testimony prepared for the Subcommittee on Domestic Monetary Policy, Technology and Economic Growth of the US House of Representatives Committee on Financial Services, March 29, 2001
} 
Conclusions for Monetary Policy. Monetary policy over the past decade has done an extraordinary job and has already been widely and appropriately praised. Going forward, monetary policy faces some tough challenges and the likelihood that future economic outcomes will not be as favorable as those experienced in the new economy of the 1990s.

Monetary policy did the right things at the right times, but had the fortune to be operating in an economy where the growth potential was expanding. Even if the trend of strong productivity growth continues, it seems likely that the dollar will weaken substantially ${ }^{43}$, the stock market will perform less well and the unemployment inflation tradeoff will worsen. A lot of the punch in the punch bowl has already been drunk.

In the face of the sharp demand slowdown that started in mid-2000, the Fed has chosen to act aggressively to restore confidence and offset the decline, and I support that policy.

If the productivity trend falters, however, it will not be within the power of monetary policy to solve the macroeconomic problems that emerge. The decline in the dollar would be sharper and likely accompanied by further weakness in the stock market and consumption. To bolster demand, sustained low interest rates would be called for, but the difficulty would be that, with slow productivity growth, the current pace of wage and compensation increases would not be consistent with the low pace of core inflation achieved in recent years. Readjusting to slow productivity growth again would take some time and considerable cost.

New Uncertainties. Since this paper was written for the conference, there has been additional economic data that indicate economic weakness. In addition, the terrorist attacks on New York and Washington have created at least a short-term economic disruption. This is not the place to attempt an analysis of the impact of the attacks or to try and make short run forecasts of when the US economy will recover. The immediate priority is to try and restore confidence and avoid a deep recession; and concerns about the size of the budget surplus in 2001 should be set aside. Given the need for additional defense and security spending, it will be even more difficult to sustain budget surpluses. It may be appropriate to revisit the out-year tax cuts and decide whether they are really justified in the current difficult situation.

\footnotetext{
${ }^{43}$ C. Fred Bergsten has pointed out (2001) that the strong dollar and resulting large external imbalances have been essential elements in the US economic performance and at the same time they have helped sustain demand in the rest of the world. Today, the strong dollar is having a negative impact, and a serious drag on the US manufacturing sector. Exchange rates are hard to forecast, but the likelihood of dollar weakness over the next few years is very high. While helping to correct the external imbalance, a declining dollar can add to inflationary pressure and limit the Fed's freedom of action.
} 


\section{CONCLUSIONS ON THE MACROECONOMIC IMPLICATIONS OF THE NEW ECONOMY}

An increase in the pace of advance in information technology, operating in an environment of increased globalization, intense competition and sound monetary and fiscal policy spurred improved economic performance in the 1990s.

The increase in the rate of productivity growth in the second half of the 1990s has been one of the most important factors at work in driving faster GDP growth, lower inflation, lower unemployment, faster real wage growth, a strong stock market, an inflow of capital, budget surpluses, and improved living standards.

The increase in the rate of productivity growth is linked to IT, through the rapid growth in the high-tech sector itself and the resulting decline in capital goods prices. Strong demand from best practice competitive traditional industries, notably service industries, has been a key driver of the high-tech sector. In turn, the new technologies are changing the way traditional industries operate.

Europe lacks a high-tech sector of comparable size to that in the United States--however, Japan has such a sector. Both regions lag the United States in the productive use of IT. The reasons for this are not new ones. Barriers to change and the evolution of industries, and limits on competition with world best practice companies discourage growth and productivity.

The term "new economy" may be the best available description of changes taking place, but is a dangerous term because it implies greater certainty about the future than actually exists. If trend productivity growth were to slow sharply, this would unravel many of the favorable economic trends enjoyed in the 1990s. Not only would growth be slower, but also unemployment and inflation would both be higher, at least for a while. Fiscal policy should be based on a cautious view of future trends, until we know for sure where the economy is headed. Monetary policy may face tougher challenges ahead. 


\section{REFERENCES}

Abraham, Katherine G., and John Haltiwanger, "Real Wages and the Business Cycle," Journal of Economic Literature, 33 (3), September 1995, 1215-64.

van Ark, Bart, "The Renewal of the Old Economy: An International Comparative Perspective," Mimeo, University of Groningen and the Conference Board, June 2001.

Ark, Bart van, and Robert H. McGuckin, Performance 2000: Productivity, Employment, and Income in the World's Economies, New York: The Conference Board, 2001.

Baily, Martin Neil, "Stabilization Policy and Private Economic Behavior," Brookings Papers on Economic Activity, 1:1978, 11-59.

Baily, Martin Neil, "Productivity and the Services of Capital and Labor," Brookings Papers on Economic Activity, 1:1981, 1-50.

Baily, Martin Neil, Charles Hulten and David Campbell, "Productivity Dynamics in Manufacturing Plants," Brookings Papers on Economic Activity. Micro: 1992, 187-268.

Baily, Martin Neil, Eric J. Bartelsman and John Haltiwanger, "Labor Productivity: Structural Change and Cyclical Dynamics," Review of Economics and Statistics, 83(3), August 2001, 420-33.

Baily, Martin Neil and Robert M. Solow, "International Productivity Comparisons Built from the Firm Level," Journal of Economic Perspectives, 15(3), Summer 2001, forthcoming.

Ball, Laurence, and Robert Moffitt, "Productivity Growth and the Phillips Curve," Photocopy. Johns Hopkins University, January 2001.

Barro Robert J., Determinants of Economic Growth, Cambridge, MA: MIT Press, 1997.

Basu, Susanto, John G. Fernald, and Matthew D. Shapiro, "Productivity Growth in the 1990s: Technology, Utilization, or Adjustment," presented at the Carnegie-Rochester conference, Pittsburgh, revised version, June 9, 2001.

Bergsten C. Fred, "Strong Dollar, Weak Policy," International Economy, July/August 2001, 8-10, 40-41.

Bergsten, C. Fred, Takatoshi Ito, and Marcus Noland, No More Bashing: Building a New JapanUnited States Economic Relationship, Washington, DC: Institute for International Economics, forthcoming.

Blanchard, Olivier, and John Simon, "The Long and Large Decline in U.S. Output Volatility," prepared for the Brookings Meeting on Economic Activity, Washington, DC, March 10, 2001.

Blinder, Alan, "The Internet and the New Economy," Brookings Institution Policy Brief, 60, June 2000 .

Bosworth, Barry and George L. Perry, "Productivity and Real Wages: Is there a Real Puzzle?" Brookings Papers on Economic Activity, 1:1994, 317-36. 
Bryan, Lowell, Jane Fraser, Jeremy Oppenheimer, and Wilhelm Rall, Race for the World, Boston, MA: Harvard Business School Press, 1999.

Brynjolfsson, Erik, and Lorin Hitt, "Beyond Computation: Information Technology, Organizational Transformation and Business Practices." Journal of Economic Perspectives, 14 (4), Fall 2000, 23-48.

Burns, Arthur, "Progress Towards Economic Stability," American Economic Review, 1960, $50(1)$.

Burtless, Gary, "Comments on Katz and Krueger," Brookings Papers on Economic Activity,1999, (1), 66-72.

Cohen, Jessica, William T. Dickens and Adam Posen, "Have the New Human Resource Management Practices Lowered the Unemployment Rate," Paper presented at the Russell-Sage and Century Foundation's Sustainable Employment Conference, January 27, 2001.

Congressional Budget Office, The Budget and Economic Outlook: Fiscal Years 2002-2011, Washington, DC: US Government Printing Office, January 2001.

Council of Economic Advisers, 20 Million Jobs: January 1993-November 1999. CEA White Paper, December 3, 1999.

Council of Economic Advisers, Economic Report of the President, Washington, DC: U. S. Government Printing Office, February 2000.

Council of Economic Advisers, Economic Report of the President, Washington, DC: U. S. Government Printing Office, January 2001.

Elridge Lucy, Marilyn E. Manser, Phyliss Otto, and Brooks Robinson, "Hours Data in Productivity Measures," Photocopy. Bureau of Labor Statistics and Bureau of Economic Analysis, May 24, 2001.

Foster, Lucia, John Haltiwanger and C. J. Krizan, "The Link Between Aggregate and Micro Productivity Growth: The Evidence from Retail Trade," Mimeo, Bureau of the Census, Washington, DC, July 2001.

Greenwood, Jeremy, and Boyan Jovanovic, "The Information-Technology Revolution and the Stock Market," American Economic Review, 1999, 89 (2), 116-22.

Gullickson, William, and Michael J. Harper, "Bias in Aggregate Productivity Trends Revisited," Mimeo, Bureau of Labor Statistics, July 2001.

Goldman Sachs Investment Research, E-Commerce/Internet: B2B: $2 B$ or Not 2B? New York: Goldman Sachs, November 1999.

Gust, Christopher, and Jaime Marquez, "Productivity Developments Abroad," Federal Reserve Bulletin, October 2000, 665-81. 
Gordon, Robert J., "Foundations of the Goldilocks Economy: Supply Shocks and the TimeVarying NAIRU," Brookings Papers on Economic Activity, 1998, (2), 297-346.

Gordon, Robert J., "Does the 'New Economy' Measure up to the Great Inventions of the Past?" Journal of Economic Perspectives, Fall 2000, 14(4), 49-74.

Gordon, Robert J., "Does the 'New Economy' Measure up to the Great Inventions of the Past?" updated table 2001a.

Gordon, Robert J., "Did the Productivity Revival Spill Over from Manufacturing to Services? Conflicting Evidence from Four Data Sources." Paper presented at the NBER productivity workshop, July 27, 2001b.

Hall, Robert E., "E-Capital: The Link between the Stock Market and the Labor Market in the 1990s," Brookings Papers on Economic Activity, 2000, (2), 73-118.

Jorgenson, Dale W., and Kevin J. Stiroh, "Raising the Speed Limit: U.S. Economic Growth in the Information Age," Brookings Papers on Economic Activity, 2000, (1), 125-211.

Jorgenson, Dale W., and Kevin J. Stiroh, "Raising the Speed Limit: U.S. Economic Growth in the Information Age," updated table, 2001.

Jorgenson, Dale W., "Information Technology and the US Economy," American Economic Review, 91 (1) March, 2001, 1-32.

Katz, Lawrence F., and Lawrence H. Summers, "Industry Rents: Evidence and Implications," Brookings Papers on Economic Activity, Microeconomics, 1989.

Katz, Lawrence F., and Alan B. Krueger, "The High-Pressure U.S. Labor Market of the 1990s," Brookings Papers on Economic Activity, 1999, (1), 1-66.

Kuttner Kenneth N. and Adam Posen "The Great Recession: Lessons for Macroeconomic Policy from Japan," paper presented at the Brookings Panel Meeting, Washington, DC, September 6-7, 2001.

Lawrence, Robert Z., and Matthew J. Slaughter, "International Trade and American Wages in the 1980s: Giant Sucking Sound or Small Hiccup?” Brookings Papers on Economic Activity, Microeconomics, 2:1993, 161-210.

Litan, Robert E., "Projecting the Economic Impact of the Internet," American Economic Review, May 2001(Papers and Proceedings), 91 (2), May, 2001.

Markoff, John, "Researchers Make an Ultra-Tiny Chip" New York Times, National section page 30, Sunday, June 10, 2001.

McConnell, M., and G. Perez-Quiros, "Output Fluctuations in the United States: What Has Changed Since the Early 1980s?” American Economic Review, December 2000, 90 (5), 1464-76.

McKinsey Global Institute, Removing Barriers to Growth and Employment in France and Germany, Washington DC: McKinsey Global Institute, March 1997. 
McKinsey Global Institute, Why the Japanese Economy is not Growing: Micro Barriers to Productivity Growth, Washington, DC: McKinsey Global Institute, July 2000.

Nordhaus, William D., "Productivity Growth and the New Economy," Working Paper 8096, National Bureau of Economic Research, January 2001.

Oliner Stephen D., and Daniel E. Sichel, "The Resurgence of Growth in the Late 1990s: Is Information Technology the Story?" Journal of Economic Perspectives, Fall 2000, 14(4), 3-32.

Oliner, Stephen D., and Daniel E. Sichel, "The Resurgence of Growth in the Late 1990s: Is Information Technology the Story?” updated tables, 2001.

Organization for Economic Cooperation and Development, A New Economy: The Changing Role of Innovation and Information Technology in Growth, Paris: OECD, 2000a.

Organization for Economic Cooperation and Development, OECD Information Technology Outlook: ICTs, E-Commerce and the Information Economy, Paris: OECD, $2000 \mathrm{~b}$.

Posen, Adam S., "Finance and Changing U.S.-Japan Relations: Convergence without Leverage until Now," Working Paper 01-8, Institute for International Economics, 2001.

Posen, Adam S., "Japan 2001: Decisive Action or Financial Crisis," International Economics Policy Brief 01-4, Institute for International Economics, March 2001.

Roberts, John M., "Estimates of the Productivity Trend Using Time-Varying Parameter Techniques," Board of Governors of the Federal Reserve System, March 2001.

Schreyer, Paul, "Computer Price Indices and International Growth and Productivity Comparisons", Growth Project Background Papers, OECD, Paris, 2001.

Shapiro, Roy, "Supply Chain Coordination: The Journey," presentation at the Harvard Business School, November 1, 2000

Sharpe, Andrew, "The Productivity Renaissance in the U.S. Service Sector," International Productivity Monitor, Center for the Study of Living Standards, Fall 2000, 1, 6-8.

Robert J. Shiller, Irrational Exuberance, Princeton University Press, 2000.

Sims, Christopher, "Comments on Katz and Krueger," Brookings Papers on Economic Activity, 1999, (1), 79.

Stiroh, Kevin, "Information Technology and the U.S. Productivity Revival: What Do the Industry Data Say?” Mimeo, Federal Reserve Bank of New York, January 2001.

Stock, James H., "Comments on Gordon," Brookings Papers on Economic Activity, 1998, (2), 334-41.

Wise, Richard, and David Morrison, "Beyond the Exchange: The Future of B2B," Harvard Business Review, November-December 2000, 78 (6), 86-96. 


\section{Table 1: Indicators of Macroeconomic Performance}

$\begin{array}{cccccc}\text { Real GDP } & \begin{array}{c}\text { Real GDP } \\ \text { per capita } \\ \text { Growth }\end{array} & \begin{array}{c}\text { Average } \\ \text { Unemployment }\end{array} & \begin{array}{c}\text { Average } \\ \text { Core } \\ \text { Inflation }^{b}\end{array} & \begin{array}{c}\text { Current } \\ \text { Account } \\ \text { Balance }^{\text {a, c }}\end{array} \\ 1959-73 & 4.2 & 2.9 & 4.9 & 2.7 & 0.4 \\ 1973-90 & 2.9 & 1.9 & 7.0 & 5.9 & -1.1 \\ 1990-00 & 3.2 & 2.2 & 5.6 & 2.4 & -1.9 \\ 1990-95 & 2.4 & 1.3 & 6.6 & 3.0 & -1.0 \\ 1995-00 & 4.1 & 3.2 & 4.6 & 1.7 & -2.7\end{array}$

Sources: Bureau of Economic Analysis (Real GDP Growth, Real GDP Per Capita Growth, PCE, Current Account, GDP)

Bureau of Labor Statistics (Unemployment, Implicit Price Deflator Nonfarm Business Sector)

Notes: a) Averages over 1960-73, 74-90, 91-00,91-95, and 96-00.

b) Chain price index for personal consumption expenditure, excluding food and energy.

c) Current account balance as a percentage of GDP. 


\section{Table 2: Decomposition of the Productivity Acceleration}

Percent per year, 1995-2000 compared to 1973-1995, non-farm business (NF)

1. Labor productivity NF

Oliner-Sichel

1.38

n.a.

0.70

$-0.26$

n.a.

0.04

0.90

0.31

0.59
Council of

Economic Advisers

1.63

0.04

0.62

$-0.23$

n.a.

0.00

1.19

0.18

1.00

Sources: Oliner and Sichel (2000, updated 2001), Gordon (2000, updated 2001), CEA (2001), Jorgenson and Stiroh (2000, updated 2001) Notes: n.a. - not applicable

a. Compares 1995-99 with 1973-95. Includes consumer durables and farm sector.

b. IT related MFP 


\section{Table 3: Labor Productivity Growth in US Industries}

GDI Orginating per Full-Time Equivalent Employee,

Average Annual Percentage Changes, Selected Periods

\begin{tabular}{|c|c|c|c|}
\hline & $1989-95$ & 1995-99 & Difference \\
\hline Private Industries ${ }^{a}$ & 0.88 & 2.31 & 1.43 \\
\hline Agriculture & 0.34 & 1.18 & 0.84 \\
\hline Mining & 4.56 & 4.06 & -0.50 \\
\hline Construction & -0.10 & -0.89 & -0.79 \\
\hline Manufacturing & 3.18 & 4.34 & 1.16 \\
\hline Durables & 4.34 & 6.84 & 2.51 \\
\hline Non-Durables & 1.65 & 1.07 & -0.59 \\
\hline Transportation & 2.48 & 1.72 & -0.76 \\
\hline Trucking/ Warehousing & 2.09 & -0.73 & -2.82 \\
\hline Transportation by Air & 4.52 & 4.52 & 0.00 \\
\hline Other Transportation & 1.51 & 2.14 & 0.63 \\
\hline Communication & 5.07 & 2.66 & -2.41 \\
\hline Electric / Gas / Sanitary & 2.51 & 2.42 & -0.09 \\
\hline Wholesale Trade & 2.84 & 7.84 & 4.99 \\
\hline Retail Trade & 0.68 & 4.93 & 4.25 \\
\hline FIRE & 1.70 & 2.67 & 0.97 \\
\hline Finance & 3.18 & 6.76 & 3.58 \\
\hline Insurance & -0.28 & 0.44 & 0.72 \\
\hline Real Estate & 1.38 & 2.87 & 1.49 \\
\hline Services & -1.12 & -0.19 & 0.93 \\
\hline Personal Services & -1.47 & 1.09 & 2.55 \\
\hline Business Services & -0.16 & 1.69 & 1.85 \\
\hline Health Services & -2.31 & -1.06 & 1.26 \\
\hline Other Services & -0.72 & -0.71 & 0.01 \\
\hline ICT Intensive Half & 2.43 & 4.18 & 1.75 \\
\hline Non-ICT Intensive Half & -0.10 & 1.05 & 1.15 \\
\hline
\end{tabular}




\section{Table 4: Annual growth rates- GDP per capita}

selected countries and years, percent per year

$\begin{array}{lccccc} & 1970 \mathrm{~s} & 1980 \mathrm{~s} & 1990-95 & 1995-99^{\mathrm{e}} & 1990-99^{\mathrm{e}} \\ \text { Africa }^{\mathrm{a}} & 1.38 & -0.27 & -1.37 & 1.13 & -0.27 \\ \text { Latin America }^{\mathrm{b}} & 3.03 & -0.92 & 1.86 & 1.15 & 1.55 \\ \text { India }^{\text {China }} & 0.67 & 3.44 & 2.84 & 4.65 & 3.64 \\ \text { Asian Tigers }^{c} & 3.14 & 5.72 & 7.35 & 5.75 & 6.64 \\ \text { Japan }^{\text {Europe }}{ }^{d} & 5.93 & 6.59 & 6.41 & 2.04 & 4.44 \\ \text { US } & 3.33 & 3.53 & 1.11 & 0.63 & 0.87 \\ & 2.50 & 2.06 & 0.96 & 2.25 & 1.60 \\ & 2.09 & 1.81 & 1.05 & 3.30 & 2.16\end{array}$

Source: University of Groningen and The Conference Board, GGDC Total Economy Database,

First Quarter 2001, http://www.eco.rug.nl/ggdc, author's calculations

a) Africa: Cote d'Ivore, Egypt, Ethiopia, Ghana, Kenya, Morocco, Nigeria,

South Africa, Tanzania, Democratic Republic of Congo

b) Latin America: Argentina, Brazil, Chile, Colombia, Mexico, Peru, Venezuela

c) Asian Tigers: Hong Kong, Singapore, South Korea, Taiwan, Thailand

d) Europe: Austria, Belgium, Denmark, Finland, France, Germany, Ireland, Italy,

Netherlands, Norway, Portugal, Spain, Sweden, Switzerland, UK

e) Through 2000 for Europe, Japan and US 


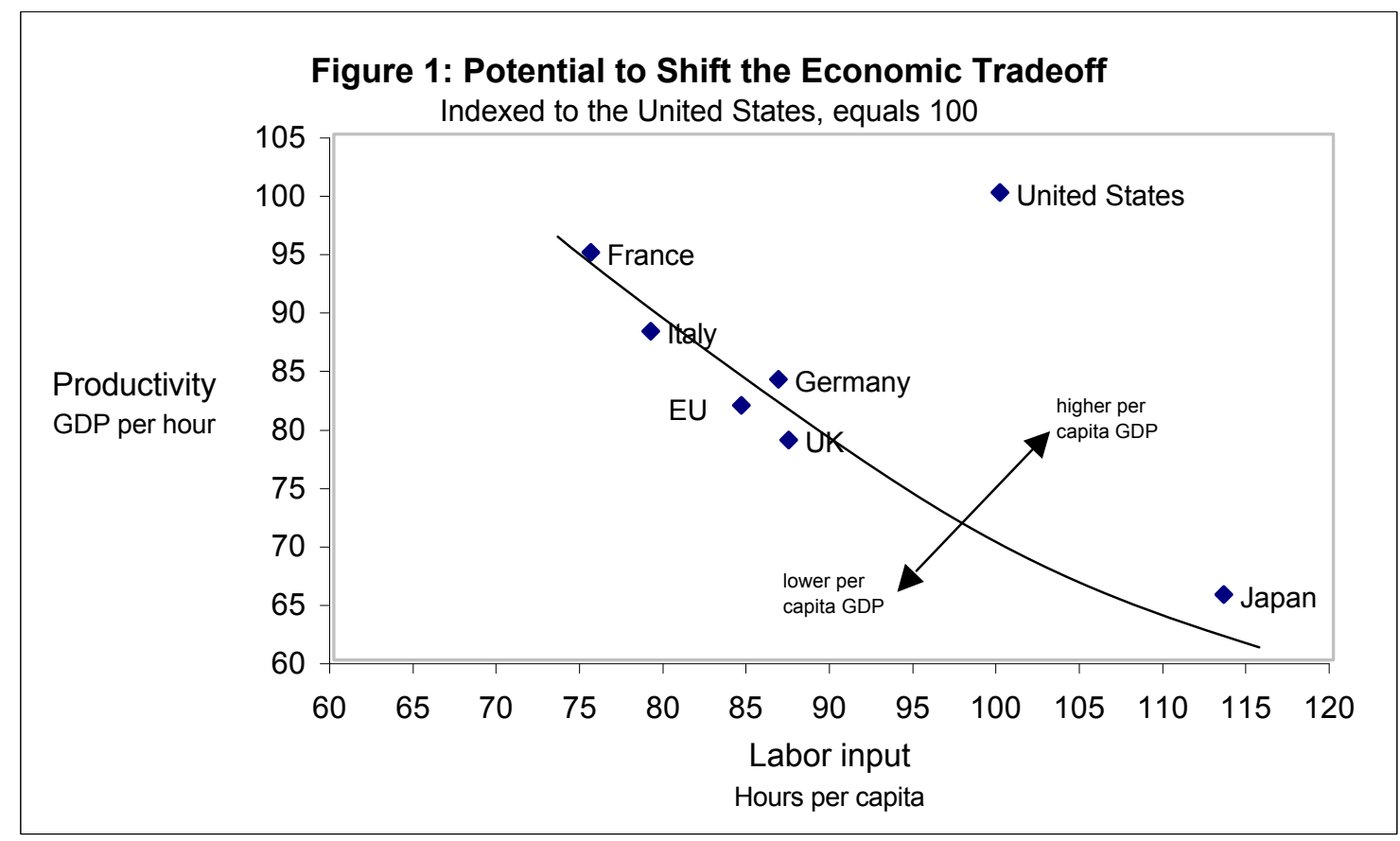




\section{Table 5: Real Wage Growth and Acceleration}

\begin{tabular}{|c|c|c|c|c|c|c|}
\hline & \multicolumn{3}{|c|}{ Using Core PCE ${ }^{a}$} & \multicolumn{3}{|c|}{ Using Core $\mathrm{CPI}^{\mathrm{b}}$} \\
\hline & $\begin{array}{c}\text { Av. Hourly } \\
\text { Earnings }\end{array}$ & $\begin{array}{c}\text { Comp. Per } \\
\text { Hour }\end{array}$ & $\begin{array}{l}\text { Employment } \\
\text { Cost Index }\end{array}$ & $\begin{array}{c}\text { Av. Hourly } \\
\text { Earnings }\end{array}$ & $\begin{array}{c}\text { Comp. Per } \\
\text { Hour }\end{array}$ & $\begin{array}{l}\text { Employment } \\
\text { Cost Index }\end{array}$ \\
\hline $1978-1995^{d}$ & -0.50 & 0.47 & 0.45 & -0.65 & 0.32 & 0.25 \\
\hline $1995-2000$ & 2.03 & 2.39 & 1.73 & 1.47 & 1.82 & 1.17 \\
\hline Change * & 2.54 & 1.92 & 1.28 & 2.12 & 1.51 & 0.92 \\
\hline \multicolumn{7}{|c|}{ Sources: Bureau of Labor Statistics, Bureau of Economic Analysis } \\
\hline \multicolumn{7}{|c|}{ Notes: a) Chain price index for personal consumption expenditure, excluding food and energy } \\
\hline \multicolumn{7}{|c|}{ b) Consumer price index U-RS, excluding food and energy } \\
\hline \multicolumn{7}{|c|}{ c) Employment cost index, private industry, all workers (total compensation) } \\
\hline \multicolumn{7}{|c|}{ d) $1980-1995$ for the employment cost index figures } \\
\hline
\end{tabular}




\section{Table 6: The Misery Index}

percentage points, annual averages over

the periods shown

$\begin{array}{cccc} & \begin{array}{c}\text { Standard } \\ \text { Index }^{a}\end{array} & \begin{array}{c}\text { With Core } \\ \text { CPI }^{b}\end{array} & \begin{array}{c}\text { With Core } \\ \text { PCE }\end{array} \\ \text { 1961-1970 } & 7.66 & \text { n.a. } & 7.31 \\ 1971-1980 & 14.50 & \text { n.a. } & 12.85 \\ 1981-1990 & 11.63 & 12.04 & 11.63 \\ 1991-1995 & 9.38 & 9.50 & 9.31 \\ 1996-2000 & 7.15 & 6.87 & 6.28\end{array}$

Sources: Bureau of Labor Statistics, Bureau of Economic Analysis

Notes: a) Published CPI inflation (CPI-U) plus civilian unemployment rate

b) CPI-U-RS ex food and energy plus civilian unemployment rate

c) PCE ex food and energy plus civilian unemployment rate 
Figure 2: The Increase in Net Worth in the 1990s

Pulled up Consumption

Years of Income Net Worth-to-Income Ratio and Consumption Rate

Percent of Income

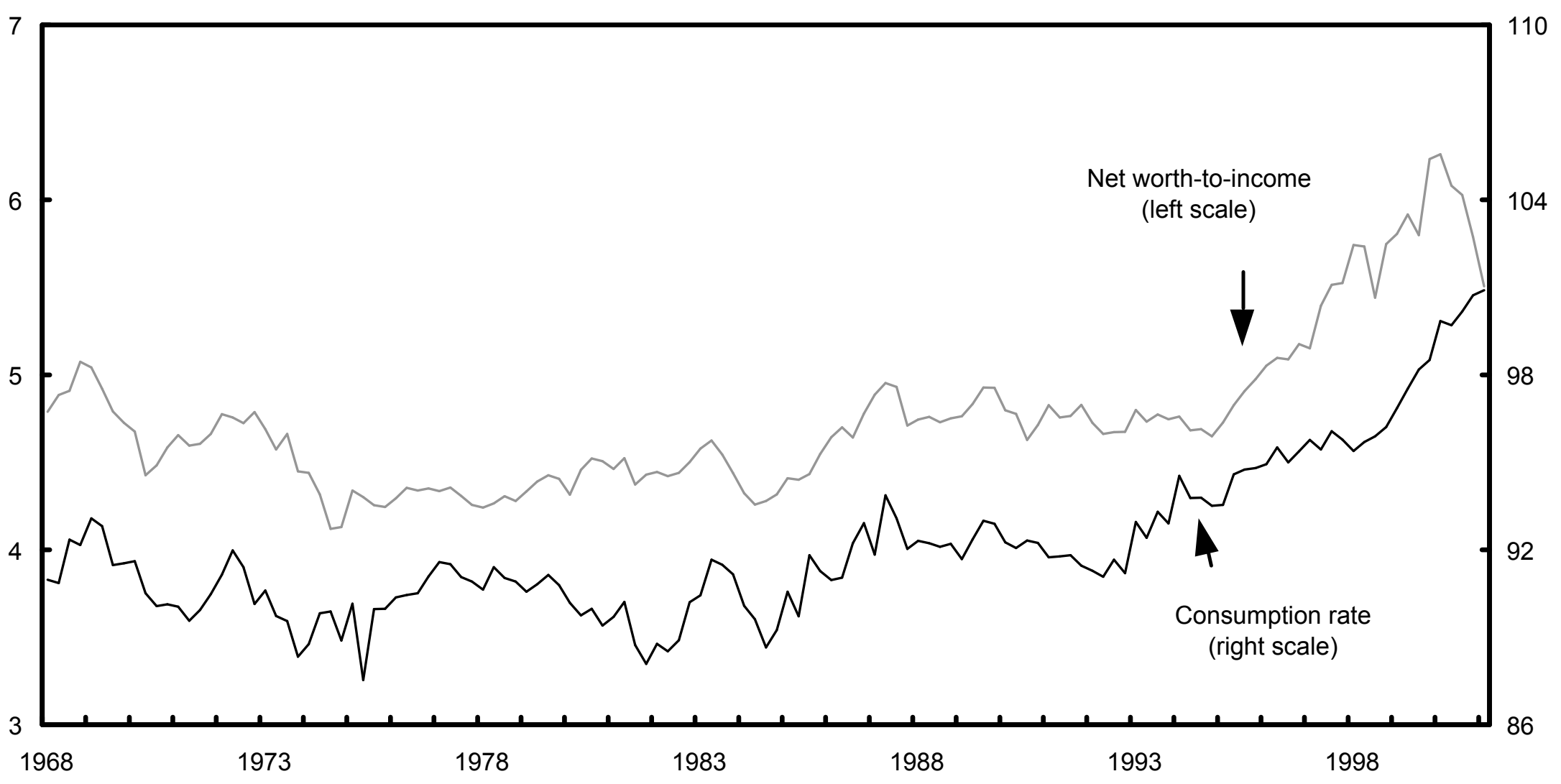

Note: The personal consumption rate is the ratio of personal outlays to disposable personal income. Shaded areas represent periods of recession.

Sources: Bureau of Economic Analysis and Board of Governors of the Federal Reserve System. 


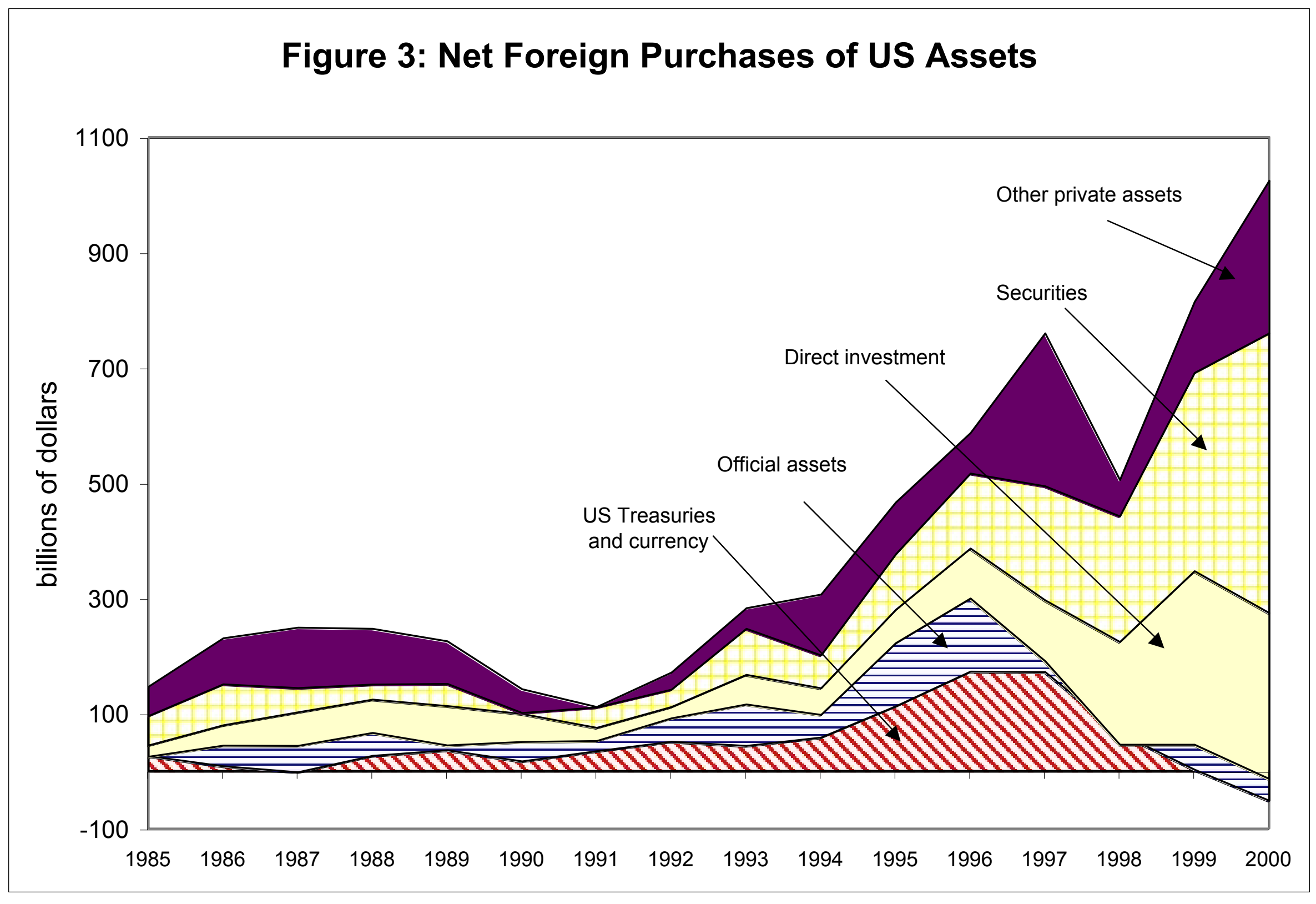




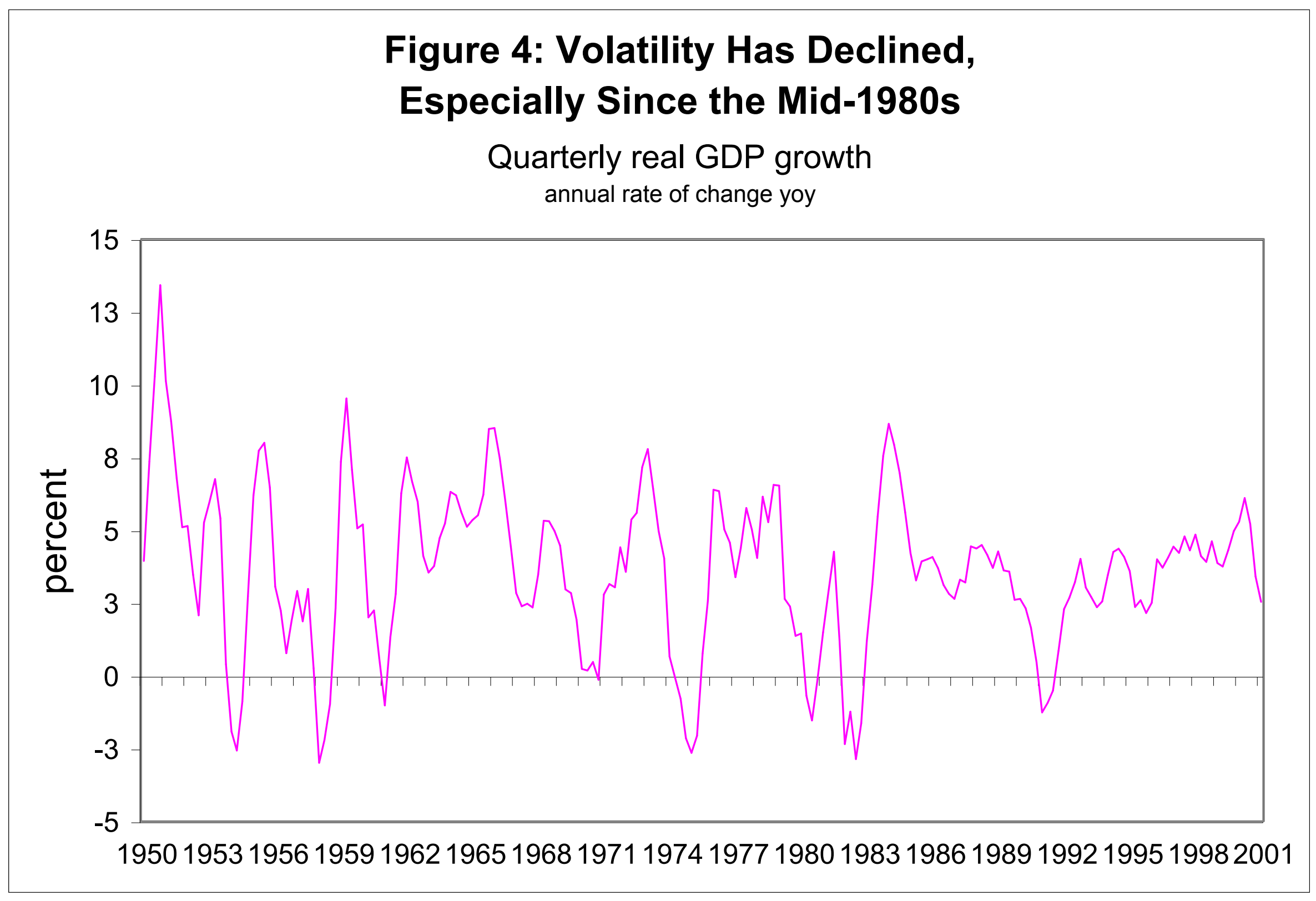




\section{Table 7: Magnitude of Economic Slowdown}

$\begin{array}{lccc} & \begin{array}{c}\text { Growth Rate } \\ \text { Up to Peak }\end{array} & \begin{array}{c}\text { Growth Rate } \\ \text { After Peak }\end{array} & \\ \text { 1948-IV } & 3.7 & -0.7 & \text { Difference } \\ 1953-I I I & 5.6 & -2.6 & -4.3 \\ 1957-I I I & 3.1 & -4.0 & -8.1 \\ 1960-I I & 2.1 & -0.7 & -7.1 \\ 1969-I V & 1.9 & 1.3 & -2.7 \\ 1973-I V & 4.1 & -2.1 & -0.7 \\ 1980-I & 1.5 & -0.4 & -6.2 \\ 1981-I I I & 4.4 & -3.1 & -1.9 \\ 1990-I I I & 1.7 & -1.0 & -7.5 \\ 2000-I I & 5.3 & 1.5 & -2.6 \\ & & & -3.8\end{array}$

Notes: a Average annual growth rate for peak quarter and three preceding quarters $b$ Average annual growth rate for three quarters following the peak quarter Source: Bureau of Economic Analysis, author's analysis 


\section{Table 8: Percent Contribution to the Growth Slowdown}

$\begin{array}{ccccccc} & \text { Inventories } & \begin{array}{c}\text { Equipment } \\ \text { \& Software }\end{array} & \begin{array}{c}\text { Other } \\ \text { Investment }\end{array} & \begin{array}{c}\text { Private } \\ \text { Consumption }\end{array} & \begin{array}{c}\text { Net } \\ \text { Exports }\end{array} & \begin{array}{c}\text { Government } \\ \text { Consumption }\end{array} \\ 1948-I V & 89 & 38 & 11 & 14 & -56 & 3 \\ 1953-I I I & 11 & 25 & -2 & 31 & -8 & 42 \\ 1957-I I I & 23 & 26 & 2 & 30 & 18 & 0 \\ 1960-I I & 16 & 46 & -10 & 88 & 5 & -45 \\ 1969-I V & 12 & 65 & 23 & 27 & -21 & 1 \\ 1973-I V & 44 & 13 & 15 & 19 & 15 & -8 \\ 1980-I & -2 & 29 & 13 & 34 & -27 & 54 \\ 1981-I I I & 61 & 17 & 16 & 17 & -10 & -1 \\ 1990-I I I & 41 & 8 & 25 & 67 & -41 & 0 \\ 2000-I I & 50 & 33 & -2 & 26 & -16 & 9 \\ \text { Average } & 34 & 30 & 9 & 35 & -14 & 5 \\ \text { Median } & 32 & 28 & 12 & 29 & -13 & 0\end{array}$

